\title{
O EFEITO DO USO DO ÓLEO DE VÍSCERAS DE AVES OXIDADO NO DESEMPENHO DE FRANGOS DE CORTE E NA ESTABILIDADE OXIDATIVA DA CARNE DA SOBRECOXA
}

\section{ALine Mondini CaLil RacanicCI}

Tese apresentada à Escola Superior de Agricultura "Luiz de Queiroz", Universidade de São Paulo, para obtenção do título de Doutor em Agronomia, Área de Concentração: Ciência Animal e Pastagens.

P I R A C I C A B A

Estado de São Paulo - Brasil

Julho - 2004 


\section{O EFEITO DO USO DO ÓLEO DE VÍSCERAS DE AVES OXIDADO NO DESEMPENHO DE FRANGOS DE CORTE E NA ESTABILIDADE OXIDATIVA DA CARNE DA SOBRECOXA}

\section{Aline Mondini Calil Racanicci}

Engenheiro Agrônomo

Orientador: Prof. Dr. JOSÉ FERNANDO MACHADO MENTEN Co-orientadora: Profa. Dra. MARISA A. B. REGITANO d'ARCE

Tese apresentada à Escola Superior de Agricultura "Luiz de Queiroz", Universidade de São Paulo, para obtenção do título de Doutor em Agronomia, Área de Concentração: Ciência Animal e Pastagens.

P I R A C I C A B A

Estado de São Paulo - Brasil

Julho - 2004 
Dados Internacionais de Catalogação na Publicação (CIP)
DIVISÃO DE BIBLIOTECA E DOCUMENTAÇÃO - ESALQ/USP

Racanicci, Aline Mondini Calil

O efeito do uso do óleo de vísceras de aves oxidado no desempenho de frangos de corte e na estabilidade oxidativa da carne da sobrecoxa/ Aline Mondini Calil

Racanicci. -- Piracicaba, 2004.

$80 \mathrm{p}$.

Tese (doutorado) - - Escola Superior de Agricultura Luiz de Queiroz, 2004.

Bibliografia.

1. Energia metabolizável 2. Frangos de corte 3. Nutrição animal 4. Peroxidação de lipídio 5. Qualidade dos alimentos I. Título

CDD 636.214 


\section{Dedico}

Ao querido Osvaldo, pelo apoio em todos os momentos, pela compreensão, amor e carinho.

Aos meus pais, Antônio Sérgio e Roseli, Aos meus sogros, Oswaldo (in memorian) e Nena, pela dedicação e pelos exemplos de vida.

A Éveri e Fábio,

Rita, Clotílzio e Isabela

por todos os momentos em família.

\section{Ofereço}

A amada Jamile, que, a cada novo dia, renova em mim a alegria pela vida, com seu amor, meiguice e ternura. 


\section{AGRADECIMENTOS}

A Deus.

Aos Profs. Menten e Marisa, meus orientadores, pelos exemplos de ética e profissionalismo, pela confiança, atenção e direcionamento em todas as etapas do meu doutorado.

Aos professores dos Departamentos de Zootecnia e de Agroindústria, Alimentos e Nutrição, aos Coordenadores do Curso de Ciência Animal e Pastagens, pelos ensinamentos e pelo apoio durante o curso.

Ao Prof. Leif Skibsted e toda sua equipe e a Profa. Grete Bertelsen, chefe do Departamento de Food Science da KVL (The Royal Veterinary and Agricultural University, da Dinamarca), pela recepção calorosa e pelos valiosos ensinamentos. Ao Prof. Søren S. Jørgensen, pelo carinho e atenção durante a minha estada.

A todos os amigos da pós-graduação, pela valorosa amizade e pela ajuda na execução dos trabalhos de pesquisa.

A todos os funcionários do Departamento de Zootecnia e do Departamento de Agroindústria, Alimentos e Nutrição, por estarem sempre dispostos a ajudar.

Ao Prof. Ariel, seus alunos e funcionários da FMVZ/Unesp - Botucatu, pela colaboração na realização do abate dos animais experimentais.

Aos professores e funcionários dos Laboratórios de Irradiação de Alimentos (Cena), de Óleos e Gorduras (Unicamp), e a Profa. Elizabeth Torres da Faculdade de Saúde Pública (USP/SP), pela colaboração nas análises.

Ao Sr. Marco Antônio Pedreira, da Fricock, pela doação do óleo de vísceras de aves em todas as fases experimentais.

A Oneida, pela amizade e orientação com as análises e técnicas analíticas.

Ao José Henrique Barbi, da Novus do Brasil, pela colaboração e apoio.

A FAPESP pela bolsa de estudos concedida e pelo suporte financeiro ao projeto de pesquisa. 


\section{SUMÁRIO}

Página

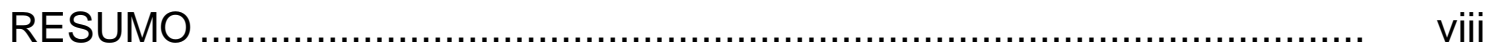

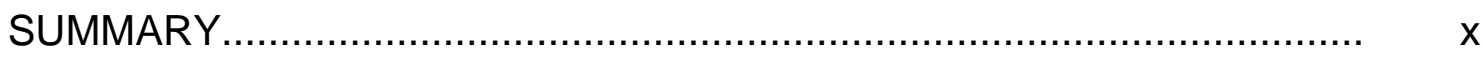

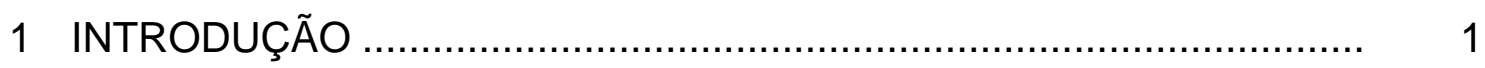

2 REVISÃO DE LITERATURA …................................................. 2

2.1 Fontes de energia utilizadas nas rações ............................................ 2

2.1.1 O óleo de vísceras de aves ....................................................... 2

2.2 Oxidação lipídica ........................................................................ 3

2.3 Os efeitos do processo oxidativo ……............................................ 7

2.3.1 Oxidação lipídica e a qualidade da carne ………………................ 8

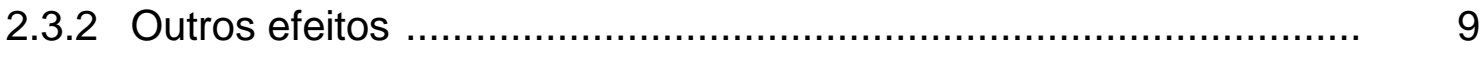

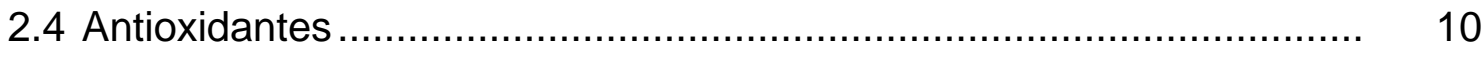

3 OXIDAÇÃO LIPÍDICA DO ÓLEO DE VÍSCERAS DE AVES REDUZ O SEU CONTEÚDO DE ENERGIA METABOLIZÁVEL PARA FRANGOS DE CORTE NA FASE DE CRESCIMENTO …................................................ 14

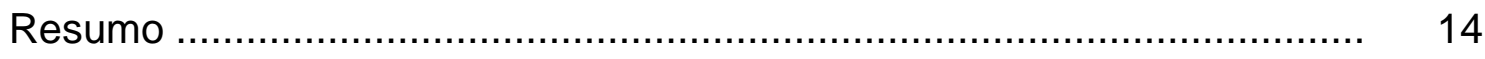

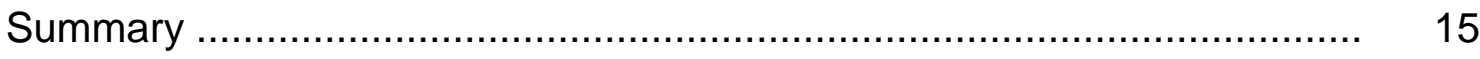

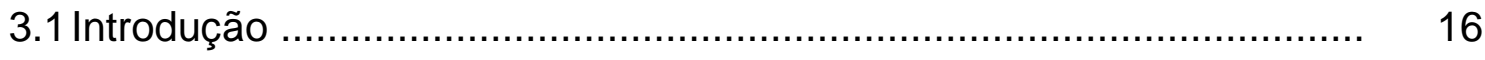

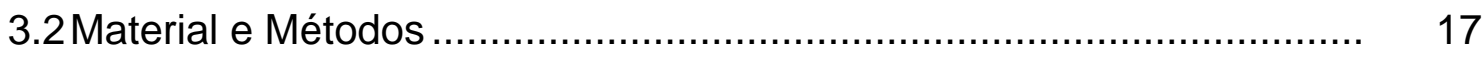

3.3 Resultados e Discussão ........................................................... 20

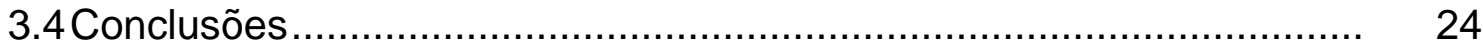


4 EFEITOS DO ÓLEO DE VÍSCERAS DE AVES OXIDADO NA RAÇÃO NO DESEMPENHO DE FRANGOS DE CORTE E NA ESTABILIDADE OXIDATIVA DA CARNE DE SOBRECOXA ARMAZENADA SOB REFRIGERAÇÃO..... 25

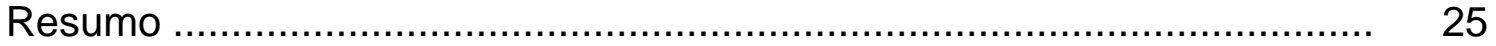

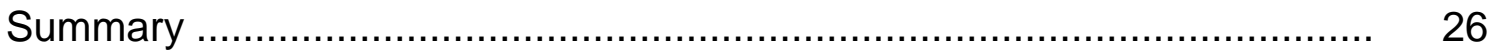

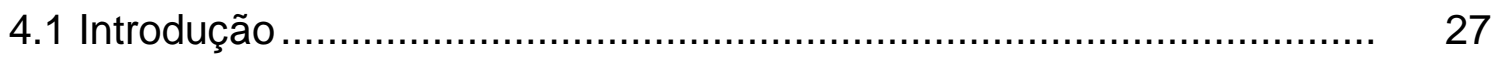

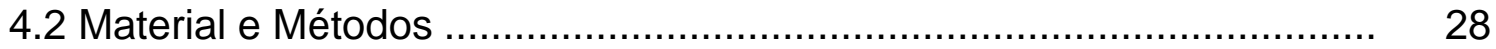

4.2.1 O óleo de vísceras de aves ......................................................... 28

4.2.2 Ensaio de desempenho ...................................................... 29

4.2.3 Abate e ensaio de armazenamento refrigerado ............................. 31

4.2.4 Análises químicas e físicas da carne de frango .............................. 32

4.2.4.1 Composição centesimal .......................................................... 32

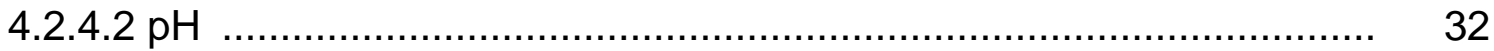

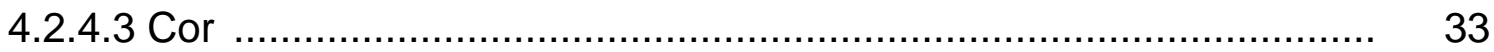

4.2.4.4 TBARS (Thiobarbituric acid reactive substances) ........................ 33

4.2.4.5 Perfil de ácidos graxos e colesterol total ................................... 35

4.2.5 Análise Estatística .............................................................. 35

4.3 Resultados e Discussão ……......................................................... 35

4.3.1 Oxidação do óleo de vísceras de aves .......................................... 35

4.3.2 Desempenho das aves ..................................................... 37

4.3.3 Características da carcaça ...................................................... 38

4.3.4 Características da carne da sobrecoxa ......................................... 41

4.3.5 Ensaio de armazenamento refrigerado ......................................... 43

4.3.5.1 Valores de TBARS ............................................................. 43

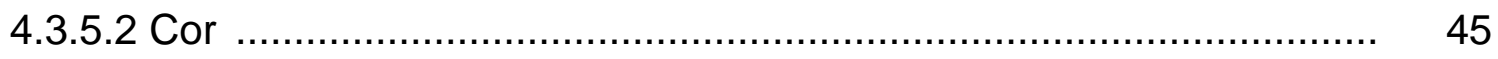

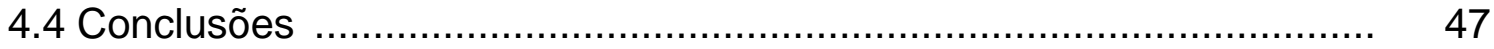

5 EFEITOS DO ÓLEO DE VÍSCERAS DE AVES OXIDADO NA RAÇÃO NO DESEMPENHO DE FRANGOS DE CORTE E NA ESTABILIDADE OXIDATIVA DA CARNE DE SOBRECOXA ARMAZENADA SOB CONGELAMENTO ... 48

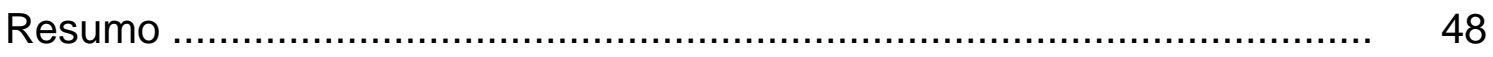




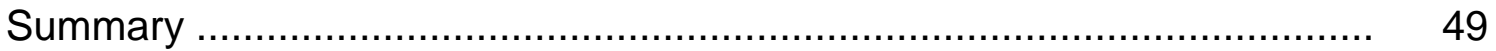

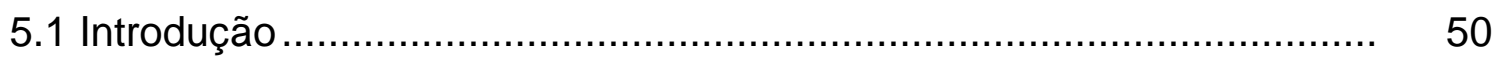

5.2 Material e Métodos ...................................................................... 51

5.2.1 O óleo de vísceras de aves ...................................................... 51

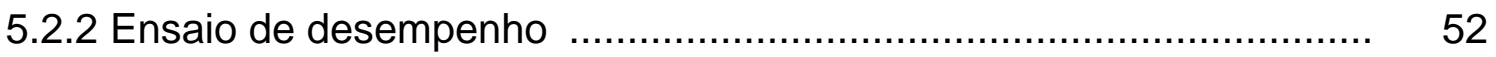

5.2.3 Abate e ensaio de armazenamento congelado............................... 54

5.2.4 Análises químicas e físicas da carne de frango ............................... 55

5.2.4.1 Composição centesimal ........................................................ 55

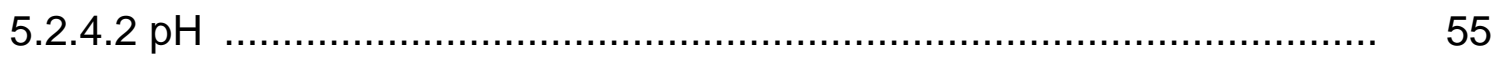

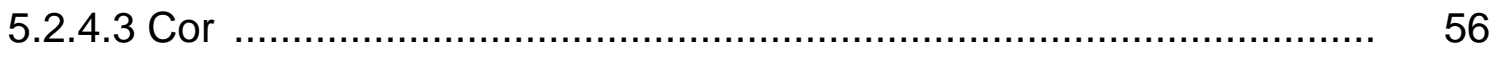

5.2.4.4 TBARS (Thiobarbituric acid reactive substances) …..................... 56

5.2.4.5 Perfil de ácidos graxos .......................................................... 57

5.2.5 Análise Estatística .............................................................. 59

5.3 Resultados e Discussão ................................................................. 59

5.3.1 Oxidação do óleo de vísceras de aves .......................................... 59

5.3.2 Desempenho das aves ........................................................... 62

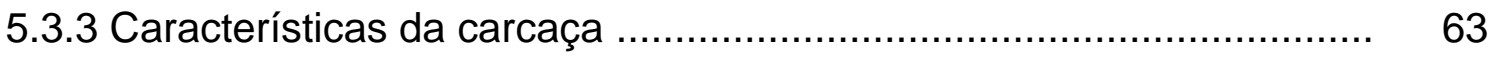

5.3.4 Características da carne da sobrecoxa ......................................... 65

5.3.5 Ensaio de armazenamento congelado ......................................... 67

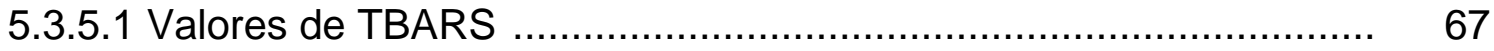

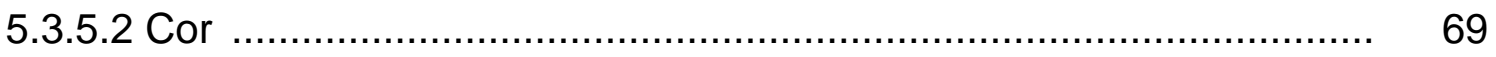

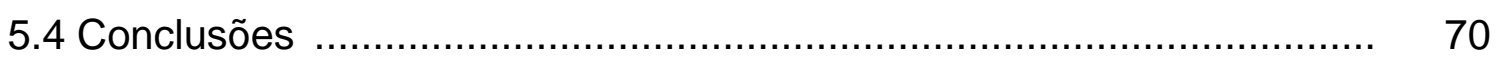

6 CONCLUSÕES GERAIS ................................................................ 71

REFERÊNCIAS BIBLIOGRÁFICAS................................................. 72 


\title{
O EFEITO DO USO DO ÓLEO DE VÍSCERAS DE AVES OXIDADO NO DESEMPENHO DE FRANGOS DE CORTE E NA ESTABILIDADE OXIDATIVA DA CARNE DA SOBRECOXA
}

\author{
Autora: ALINE MONDINI CALIL RACANICCI \\ Orientador: Prof. Dr. JOSÉ FERNANDO MACHADO MENTEN \\ Co-orientadora: Profa. Dra. MARISA A. B. REGITANO d'ARCE
}

\section{RESUMO}

Óleos e gorduras são matérias-primas imprescindíveis nas rações para frangos de corte quando se procura aumentar a densidade energética das rações e maximizar o desempenho das aves. No entanto, estes ingredientes podem apresentar baixa estabilidade e não é incomum o uso de óleos oxidados na fabricação destas rações, o que pode vir a prejudicar o desempenho dos animais e a estabilidade oxidativa da carne. Visando estudar estes aspectos foram realizados três experimentos com o fornecimento de óleo de vísceras de aves oxidado nas rações dos animais. Nestes estudos, o óleo recém extraído (fresco) foi mantido armazenado através do congelamento $\left(-18{ }^{\circ} \mathrm{C}\right)$ e o óleo oxidado foi produzido através do aquecimento prolongado a altas temperaturas. 
No primeiro experimento, foi conduzido um ensaio de metabolismo utilizando-se 48 frangos machos AgRoss de 31 a 34 dias de idade alojados em gaiolas metabólicas, para determinar os prejuízos da oxidação ao valor biológico do óleo. Foi fornecida uma dieta referência ou esta dieta com a substituição de $10 \%$ pelo óleo de vísceras fresco ou oxidado, sendo cada dieta oferecida a quatro repetições de quatro aves. O período de coleta foi de quatro dias com período prévio de três dias de adaptação às gaiolas e às rações. Os resultados obtidos e expressos na matéria original foram, tanto para a energia metabolizável aparente (EMA) como para os valores corrigidos para o nitrogênio $\left(E M A_{n}\right), 17 \%$ inferiores $(P<0,0001)$ para o tratamento óleo oxidado (7.770 e $7.595 \mathrm{kcal} / \mathrm{kg}$, respectivamente) em relação ao tratamento óleo fresco (9.240 e $9.150 \mathrm{kcal} / \mathrm{kg}$, respectivamente). O segundo e o terceiro experimentos foram conduzidos para avaliar os efeitos do fornecimento de dieta com óleo oxidado em comparação à dieta com óleo fresco sobre o desempenho das aves e sobre a estabilidade da carne de sobrecoxa armazenada sob refrigeração e congelamento, respectivamente. As aves experimentais (160 machos Cobb no segundo experimento e 200 machos AgRoss no terceiro experimento), foram alimentadas com rações contendo $4 \%$ de óleo de vísceras fresco ou oxidado dos 10 dias de idade até o abate. Em ambos experimentos, o consumo do óleo oxidado não afetou o desempenho das aves, nem tampouco as características da carcaça. Durante o período de armazenamento, as médias de $\mathrm{pH}$ e cor (valores de $L^{*}, a^{*}$ e $b^{*}$ ) não apresentaram diferenças entre os tratamentos. Contudo, a estabilidade oxidativa da carne de sobrecoxa de frangos alimentados com dietas contendo $4 \%$ de óleo oxidado foi menor, tanto para a carne resfriada, como para a congelada. Ao final dos doze dias de armazenamento resfriado, os valores de TBARS foram significativamente $(P=0,0016)$ superiores para o tratamento óleo oxidado em relação ao fresco. Para a carne congelada, os valores de TBARS apresentaram diferença estatística $(P<0,10)$ a partir do sexto mês de armazenamento. 


\title{
EFFECTS OF OXIDIZED POULTRY OFFAL FAT ON BROILER PERFORMANCE AND OXIDATIVE STABILITY OF THIGH MEAT
}

\author{
Author: ALINE MONDINI CALIL RACANICCI \\ Adviser: Prof. Dr. JOSÉ FERNANDO MACHADO MENTEN \\ Co-adviser: Profa. Dra. MARISA A. B. REGITANO-d'ARCE
}

\section{SUMMARY}

Fats and oils are widely used in poultry diets to increase energy density and improve broiler performance. However, some fats and oils are highly sensitive to oxidation during storage and the intake of oxidized feed may lead to poor peformance and decreased oxidative stability of poultry meat. Two experiments were conducted feeding broiler chickens with fresh or oxidized poultry offal fat to measure its effects on performance and meat stability. Fresh poultry fat was supplied by a local rendering and kept fresh by freezing $\left(-18{ }^{\circ} \mathrm{C}\right)$. The oxidized poultry fat was obtained by heating at high temperatures. In the first experiment, a metabolism assay was conducted using 48 AgRoss male broilers, from 31 to 34 days of age. Birds were fed a corn-soy diet or this diet 
with $10 \%$ of fresh or oxidized fat. The results of apparent metabolizable energy (AME) and N-corrected apparent metabolizable energy $\left(\mathrm{AME}_{n}\right)$ were 9,240 and $9,150 \mathrm{kcal} / \mathrm{kg}$ (as fed-basis) when fed as fresh poultry fat and 7,770 and 7,595 $\mathrm{kcal} / \mathrm{kg}$ when fed as oxidized poultry fat. These data indicate a $17 \%$ reduction on $A M E$ and $A M E_{n}$ values $(P<0.0001)$ for the oxidized fat, probably due to the negative effects of lipid oxidation. The second and the third experiments were conducted to evaluate broiler performance and oxidative stability of thigh meat stored chilled and frozen. Birds (160 male Cobb chicks in the second experiment and 200 male AgRoss chicks in the third experiment) were fed a corn-soy diet containing $4 \%$ of fresh or oxidized poultry fat from 10 days to slaughter. Intake of oxidized poultry fat had no effect on bird performance and on carcass characteristics. There were no differences on meat $\mathrm{pH}$ and color $\left(\mathrm{L}^{*}, \mathrm{a}^{*}\right.$ and $\mathrm{b}^{*}$ values) between dietary treatments during chilled and frozen storage. The inclusion of oxidized poultry fat in the birds diets depressed oxidative stability of thigh muscle during chilled and frozen storage. For the oxidized treatment, TBARS values were statistically higher $(P=0.0016)$ at the end of 12 days of chilled storage, and were also higher $(P<0.10)$ after six months of frozen storage. 


\section{INTRODUÇÃo}

Nos últimos tempos, grandes quantidades de óleos e gorduras têm sido incorporadas às rações de frangos de corte para aumentar a densidade energética das rações e, conseqüentemente, melhorar o desempenho das aves. Óleos vegetais altamente insaturados têm sido os preferidos devido a sua melhor digestibilidade, mas óleos de origem animal também têm sido utilizados com sucesso. O óleo de vísceras de aves tem como principal vantagem o baixo custo, apresentando grandes quantidades de ácidos graxos insaturados. No entanto, a suscetibilidade ao ranço oxidativo é grande, podendo provocar uma série de prejuízos ao desempenho animal e à estabilidade oxidativa da carne. Os objetivos deste estudo foram acompanhar o desenvolvimento da oxidação do óleo de vísceras de aves e quantificar o seu efeito sobre o seu valor energético do óleo fornecido a frangos de corte na fase de crescimento; verificar se a adição desta matéria-prima oxidada traria efeitos negativos sobre o desempenho das aves, características da carcaça ou da carne dos animais. E, finalmente, refletindo a crescente preocupação por parte dos consumidores com a qualidade das carnes consumidas, procurou-se estudar as conseqüências do uso do óleo oxidado nas rações de frangos de corte sobre a composição e sobre a estabilidade oxidativa da carne de sobrecoxa armazenada sob refrigeração por 12 dias e sob congelamento por nove meses. 


\section{REVISÃO DE LITERATURA}

\subsection{Fontes de energia utilizadas nas rações}

O uso de alimentos altamente energéticos como óleos e gorduras nas rações tem permitido a formulação de dietas de alta energia para frangos de corte, viabilizando aumento de produtividade e melhoria de desempenho verificados nos últimos anos.

A Avicultura de corte tem utilizado os subprodutos de abatedouros avícolas na produção de rações para frangos de corte, especialmente as farinhas de penas e vísceras, além do óleo de vísceras. A grande vantagem do uso destes subprodutos é o seu baixo custo aliado à boa qualidade da matériaprima inicial. No entanto, certos aspectos inerentes ao processamento destes produtos, como o tempo de armazenamento antes do processamento e a presença de metais catalisadores de reações de oxidação, podem comprometer a qualidade do produto final (Robey, 1994).

\subsubsection{O óleo de vísceras de aves}

O óleo de vísceras de aves é uma fonte de energia muito utilizada na produção de rações animais, mas sua composição de ácidos graxos favorece o desenvolvimento da rancidez oxidativa devido à quantidade de ácidos graxos insaturados (Tabela 1), representados pelo ácido oléico e ácido linoléico. Em função da sua estrutura química, os ácidos graxos insaturados são mais facilmente oxidados (Robey \& Shermer, 1994). 
Tabela 1. Conteúdo energético $(\mathrm{kcal} / \mathrm{kg})$ e composição percentual dos principais ácidos graxos presentes no óleo de vísceras de aves

\begin{tabular}{lccccccc}
\hline & EMV $^{1}$ & C16:0 & C16:1 & C18:0 & C18:1 & C18:2 & C18:3 \\
\hline $\begin{array}{l}\text { Óleo de } \\
\text { vísceras } \\
\text { de aves }\end{array}$ & 9.360 & 18,10 & 5,90 & 4,60 & 46,20 & 23,30 & 1,10 \\
\hline
\end{tabular}

${ }^{1} 7 \%$ de inclusão na dieta, metodologia descrita por Lessire et al.(1982)

Fonte: NRC (1994)

\subsection{Oxidação lipídica}

A oxidação é um processo extremamente importante no metabolismo normal dos animais, através do qual os nutrientes provenientes dos alimentos são oxidados com a finalidade de gerar calor, produzir energia para os processos metabólicos e transformar nutrientes em tecido corporal. Por outro lado, enquanto o oxigênio é essencial ao metabolismo, sua presença também é perigosa em função da possibilidade de ocorrência de reações de oxidação, um processo de difícil controle, que pode causar a destruição de componentes importantes dos alimentos, além de danos às estruturas celulares e aos tecidos animais (Adams, 1999).

Existem compostos que reagem espontaneamente com o oxigênio e sofrem deterioração durante o processo de oxidação, entre eles estão os óleos e as gorduras presentes nos alimentos ou adicionadas às rações, as vitaminas lipossolúveis, além de pigmentos carotenóides. O processo de rancidez oxidativa ou peroxidação lipídica é a principal causa da perda de qualidade do alimento ou da ração, afetando o seu sabor, aroma, cor e textura, além de resultar em um sério decréscimo no seu valor nutritivo (Scott, 1982).

O processo de oxidação se inicia na ligação carbono-hidrogênio adjacente à dupla ligação da cadeia de carbono, podendo ser catalisado por um grande número de fatores, especialmente fatores ambientais (umidade, calor, luz e oxigênio), presença de metais (cobre, ferro e manganês) e de enzimas 
(Adams, 1999). Trata-se de um processo bastante complexo e composto por três fases: iniciação, propagação e terminação.

Nas fases de iniciação e propagação a presença de radicais livres, que são moléculas extremamente reativas, é decisiva. Essas formas reativas são normalmente produzidas durante o metabolismo do oxigênio nos tecidos e são chamadas de espécies reativas de oxigênio (ROS - Reactive Oxygen Species). Estes compostos dividem-se em radicais (ex.: $\mathrm{O}_{2} \bullet^{-}$e $\mathrm{HO} \bullet$ ) ou não radicais (ex.: $\mathrm{H}_{2} \mathrm{O}_{2}$ ). Alguns deles são produzidos durante o metabolismo aeróbico das células vivas, como o radical superóxido $\left(\mathrm{O}_{2} \bullet^{-}\right)$, que é formado pela adição de um elétron extra ao oxigênio molecular $\left(\mathrm{O}_{2}\right)$ durante o processo de redução do oxigênio na cadeia respiratória mitocondrial. Da mesma forma, os macrófagos, quando estimulados, produzem $\mathrm{O}_{2} \bullet^{-}$e $\mathrm{H}_{2} \mathrm{O}_{2}$ durante o processo de normal de fagocitose (Combs, 1998).

Mesmo apresentando pouca reatividade química, os compostos $\mathrm{O}_{2} \bullet^{-}$e $\mathrm{H}_{2} \mathrm{O}_{2}$, quando expostos a determinados íons metálicos $\left(\mathrm{Fe}^{2+}\right.$ e $\mathrm{Cu}^{+2}$ ), formam um radical livre altamente reativo, o radical hidroxila ( $\mathrm{HO} \bullet$ ):

$$
\mathrm{O}_{2} \bullet^{-}+\mathrm{H}_{2} \mathrm{O}_{2}+\mathrm{Fe}^{+2} \longrightarrow \mathrm{O}_{2}+\mathrm{HO} \bullet+\mathrm{HO}^{-}+\mathrm{Fe}^{+3}
$$

Os metais bivalentes podem também catalisar a reação de decomposição do $\mathrm{H}_{2} \mathrm{O}_{2}$ ou do hidroperóxido $(\mathrm{ROOH})$ já produzido pela oxidação lipídica, formando os radicais $\mathrm{HO} \bullet$ ou $\mathrm{RO} \bullet$, respectivamente:

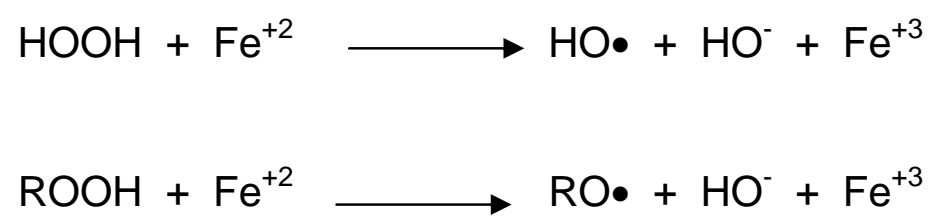

O radical hidroxila (HO•) é provavelmente o radical livre mais importante para a iniciação do processo de oxidação nos tecidos animais, uma 
vez que ele pode rapidamente remover um átomo de hidrogênio do ácido graxo insaturado. Os principais alvos do radical hidroxila (HO•) são os lipídios, especialmente os ácidos graxos insaturados da membrana celular, as proteínas e o DNA (Combs, 1998).

Os ácidos graxos insaturados da membrana celular são muito suscetíveis ao ataque dos radicais livres ( $\mathrm{HO} \bullet$ ou $\mathrm{HOO} \bullet$ ) devido a sua estrutura química, que permite a retirada de átomos de hidrogênio de um dos grupos $-\mathrm{CH}_{2}$ da cadeia carbônica e a conseqüente formação de um radical livre (-C•-), iniciando, assim, o processo de peroxidação lipídica, que pode ser observado abaixo (Figura 1).

Em seguida, estes radicais, que são instáveis, se reestruturam na forma de dienos conjugados reativos e dão origem ao radical peroxil (ROO•). Segundo Combs (1998), este radical tem a capacidade de retirar um átomo de hidrogênio de outro ácido graxo insaturado intacto, propagando uma reação em cadeia até que todo ácido graxo insaturado da membrana seja completamente oxidado a hidroperóxidos (ROOH).

Os hidroperóxidos são degradados na presença de metais como $\mathrm{Cu}^{2+}$ e $\mathrm{Fe}^{2+}$ em estado livre (íons) ou ligados a proteínas (ex.: hemoglobinas), liberando radicais que dão seqüência à cadeia de reações de oxidação e outros produtos de clivagem (ex.: malonaldeídos e alcanos). Acredita-se que esta degradação oxidativa dos ácidos graxos insaturados da membrana fosfolipídica leva a mudanças físico-químicas que resultam em disfunções da membrana celular (Combs, 1998).

Apesar da intensa produção de radicais livres durante os processos metabólicos naturais do organismo, grandes quantidades destes compostos podem ter origem exógena, sendo provenientes, por exemplo, da poluição, do consumo de alimentos oxidados, da fumaça dos cigarros, da radiação solar, dentre outros. 


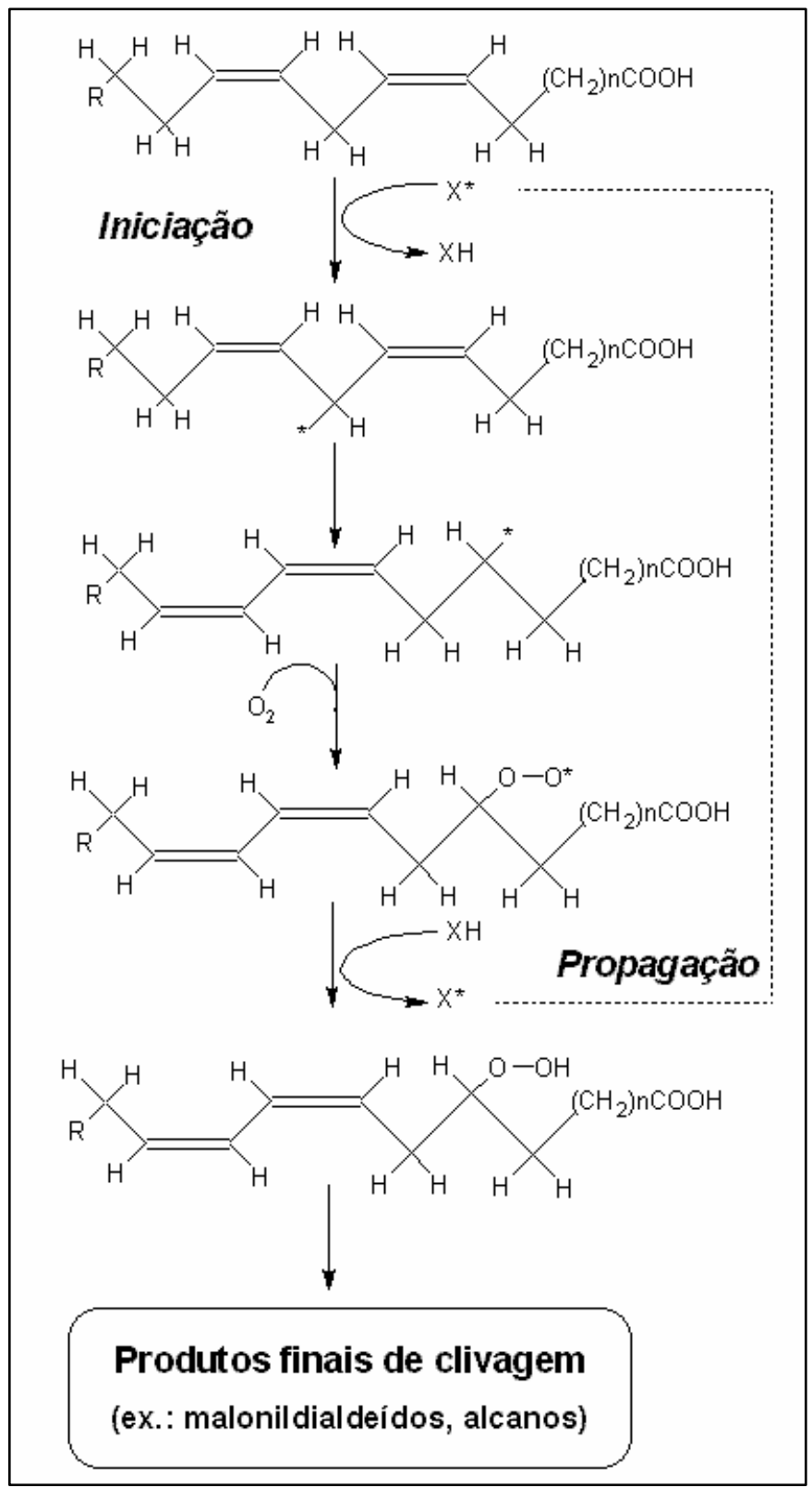

Figura 1 - As fases da oxidação lipídica. Adaptado de Combs (1998)

O processo de oxidação lipídica se instala efetivamente quando ocorre deficiência no sistema natural de proteção do organismo (antioxidantes naturais) ou quando há exposição excessiva a fatores que estimulam a produção de radicais livres, ou seja, quando fatores pró-oxidantes excedem a capacidade dos antioxidantes. 
Segundo Adams (1999), se os radicais livres não forem removidos com segurança, o estresse oxidativo pode danificar ou comprometer a saúde do animal. No decorrer do processo oxidativo, iniciado a partir da remoção do hidrogênio do ácido graxo insaturado pelo radical livre, ocorre formação de mais de 60 produtos finais, muitos dos quais são citotóxicos. Este processo autocatalítico de peroxidação lipídica nos sistemas biológicos só pode ser interrompido pela ação dos antioxidantes.

\subsection{Os efeitos do processo oxidativo}

O consumo de alimento oxidado representa riscos para a saúde, tanto para os humanos, como para os animais. Os humanos normalmente evitam o consumo de gorduras oxidadas em função do odor de ranço, no entanto, os animais muitas vezes não conseguem evitá-las, já que não têm outra opção de alimentação (Adams, 1999).

Em decorrência do consumo do alimento oxidado e da destruição de certos nutrientes durante o processo de oxidação, principalmente vitamina $\mathrm{E}$ e certos ácidos graxos, quadros de oxidação severa têm sido associados com o estresse oxidativo, como por exemplo, encefalomalácia, diátese exsudativa, distrofia muscular, necrose dos tecidos de vários órgãos, além da baixa fertilidade e taxa de eclosão (Cabel et al., 1988). Segundo Balnave (1970), a deficiência de ácidos graxos essenciais pode causar uma série de problemas nas aves, dentre eles a redução no crescimento, problemas reprodutivos, aumento no tamanho do fígado e alterações na sua composição lipídica (fígado gordo), e menor resistência a doenças. Friedman e Sklan (1997) observaram uma redução na taxa de crescimento dos animais associada com uma menor concentração do ácido graxo $\mathrm{C}_{18: 2}$ na dieta, concluindo que esta redução do crescimento foi decorrente do fornecimento marginal dos ácidos graxos essenciais.

Aliando-se a esses fatores a provável redução do conteúdo energético do alimento oxidado e a baixa eficiência da sua utilização pelos 
animais, pode-se compreender o decréscimo no desempenho verificado nos animais submetidos a estresse oxidativo (Waldroup et al., 1960; Cabel et al., 1988; Lin et al., 1989b; Sheehy et al., 1994; Engberg et al., 1996).

Além disso, a maioria dos produtos finais da oxidação, como aldeídos e cetonas, devido a sua natureza hidrofílica e seu baixo peso molecular é facilmente absorvida e levada pela corrente sangüínea até órgãos internos, onde promovem a oxidação lipídica in vivo (Adams, 1999).

Estes produtos secundários podem ser incorporados às membranas celulares dos tecidos hepático e adiposo, provocando uma série de alterações na estrutura da membrana celular, levando a mudanças na permeabilidade, viscosidade e atividade secretora da membrana e na atividade de enzimas associadas à membrana (Robey \& Shermer, 1994).

A ingestão de radicais livres provenientes da gordura oxidada presente nos alimentos pode resultar numa redução da concentração de $\alpha$ tocoferol dos tecidos e, conseqüentemente, numa menor estabilidade destes tecidos (Asghar et al., 1989; Lin et al, 1989a). A redução na quantidade do $\alpha$ tocoferol presente nas membranas subcelulares é resultado do seu uso na proteção destas membranas contra o ataque dos radicais livres originários da gordura consumida. A presença de óleo oxidado na ração de frangos de corte torna os lipídios da membrana celular muito suscetíveis a peroxidação, o que está intimamente ligado à estabilidade da carne durante o armazenamento (Asghar et al., 1989).

\subsubsection{Oxidação lipídica e a qualidade da carne}

A oxidação lipídica é o principal processo pelo qual ocorre perda de qualidade da carne e seus produtos, depois da deterioração microbiana (Gray et al., 1996). A oxidação lipídica em carnes envolve os lipídios polinsaturados das membranas celulares e está relacionada também com a oxidação dos pigmentos da carne provocando perda de cor, segundo Andersen et al. (2003). 
Logo após a morte do animal se dá o início do processo de rancidez, que aumenta de intensidade até que a carne se torne inaceitável ao consumo. Durante o processo de conversão de músculo em carne ocorre uma série de mudanças bioquímicas que acompanham o metabolismo post mortem e promovem condições para que o processo de oxidação se instale. Estas mudanças favorecem o desenvolvimento da oxidação na fração fosfolipídica altamente insaturada nas membranas subcelulares, uma vez que é improvável que os mecanismos de defesa das células do animal vivo ainda funcionem perfeitamente após o abate (Gray et al., 1996; Morrissey et al., 1998).

Os hidroperóxidos formados durante o processo de oxidação lipídica são essencialmente inodoros, contudo, eles se decompõem em uma grande variedade de compostos secundários voláteis e não-voláteis. Dentre estes, os aldeídos são os que mais contribuem para perda do aroma natural das carnes devido a sua alta taxa de formação durante o processo de oxidação lipídica. De uma maneira geral, o odor desenvolvido nas carnes armazenadas sob refrigeração pode ser atribuído mais ao mascaramento do seu aroma natural devido ao aumento do conteúdo de odores desagradáveis no material armazenado do que pela degradação do aroma original (Gray et al., 1996).

\subsubsection{Outros efeitos}

O efeito tóxico da gordura oxidada e dos produtos secundários da oxidação nas células foi demonstrado por Dibner et al. (1996), através da observação da proliferação celular no epitélio do intestino e no fígado. Nos animais alimentados com gordura oxidada houve uma acentuada redução no tempo de vida das células do epitélio intestinal e do fígado, levando a um menor aproveitamento dos alimentos e a um aumento na demanda energética e, conseqüentemente, a um aumento na exigência de mantença destes animais. Os autores sugerem que decorrem destes fatos os resultados negativos no desempenho. 
Há indicativos de que o consumo de gorduras oxidadas também esteja ligado à diminuição da resistência dos animais a doenças, uma vez que muitas das funções de proteção exercidas pelas células do sistema imune dependem da fluidez das membranas destas células. A perda da fluidez tem sido relacionada diretamente com a menor capacidade dos linfócitos em responder aos desafios (Adams, 1999).

Analisando a microflora do intestino de aves que foram alimentadas com rações contendo gordura fresca ou oxidada, Robey \& Shermer (1994) observaram alterações na população de E. coli e Lactobacillus no intestino das aves sob estresse oxidativo. A multiplicação de Lactobacillus é inibida pela presença de peróxidos, resultando num decréscimo temporário na população desta bactéria e num aumento na população de E.coli.

Verificou-se também neste estudo modificações na função intestinal, ou seja, na absorção dos nutrientes. Aves alimentadas com gordura oxidada tiveram a capacidade de absorção de glicose aumentada em resposta ao déficit de energia gerado pela baixa energia metabolizável da gordura oxidada, ou talvez esse aumento na absorção indique que as aves necessitam de mais energia quando estão sob estresse oxidativo. Estas alterações na absorção da glicose pelo intestino devem ser reações do organismo às mudanças no metabolismo de carboidratos do fígado (Robey \& Shermer, 1994).

\subsection{Antioxidantes}

Sendo a oxidação dos ácidos graxos e fosfolipídios um processo tão destrutivo, ao longo do tempo os animais desenvolveram estratégias para prevenir a oxidação celular. Os antioxidantes são substâncias que estão presentes em quantidades menores que as do substrato oxidável e que retardam ou previnem a sua oxidação. Os antioxidantes agem eliminando os radicais livres do organismo, interrompendo a seqüência de propagação e dissipando a energia reativa através do anel da sua estrutura (Robey, 1994). 
Os antioxidantes podem ser classificados pela sua origem, natural ou sintética, ou pelo seu modo de ação nas reações de oxidação, seja através da quebra da cadeia de reações, da eliminação do oxigênio do meio ou da interrupção da fase de iniciação (Adams, 1999).

Dentre os antioxidantes naturais, a vitamina E é um dos mais efetivos, apesar da baixa concentração nos tecidos (cerca de uma molécula para 2.000 moléculas de fosfolipídios da membrana). O termo vitamina $E$ é usado como uma descrição genérica para todos os derivados de tocóis e tocotrienóis que exibem a atividade biológica do $\alpha$-tocoferol. Como a vitamina $\mathrm{E}$ não pode ser sintetizada pelos animais, a sua presença nos tecidos depende da sua disponibilidade na dieta (Jensen et al., 1998). No entanto, uma vez iniciada a rancidez nos ácidos graxos insaturados, os produtos gerados neste processo destroem a vitamina E. Conseqüentemente, o uso de gordura oxidada pode levar a deficiência desta vitamina, mesmo em dietas com suplementação.

Diversos estudos têm sido conduzidos com a finalidade de estudar os efeitos da adição de níveis supranutricionais de $\alpha$-tocoferol na dieta (200 a $400 \mathrm{mg}$ de $\alpha$-tocoferil acetato/kg de ração) sobre a estabilidade das membranas biológicas e, conseqüentemente, sobre a estabilidade oxidativa de carnes durante o armazenamento (Asghar, et al. 1989; Lin et al. 1989a; Lin et al., 1989b; Galvin et al., 1997; Lauridsen et al., 1997; Sheldon et al., 1997; O'Neill et al., 1998; Bou et al., 2001; Grau et al., 2001a; Grau et al., 2001b). De uma maneira geral, a suplementação de $\alpha$-tocoferil acetato na dieta leva a um acúmulo do $\alpha$-tocoferol nos tecidos, protegendo os ácidos graxos e o colesterol presente nas membranas do processo acelerado e destrutivo de oxidação lipídica.

Sabe-se que a concentração de $\alpha$-tocoferol acumulada na carne de aves é diretamente proporcional à quantidade fornecida na dieta e ao tempo de suplementação. Segundo Morrisey et al. (1997), para otimizar as concentrações de vitamina E nos músculos e garantir estabilidade adequada, 
deve-se fornecer pelo menos $200 \mathrm{mg}$ de $\alpha$-tocoferil acetato por $\mathrm{kg}$ de ração por, no mínimo, quatro semanas antes do abate. Isso porque este estudo revelou que a completa saturação dos níveis de $\alpha$-tocoferol nos tecidos musculares ocorre somente após três a quatro semanas de fornecimento na dieta.

Além disso, este acúmulo no tecido animal depende do tipo de músculo. As carnes escuras de aves acumulam até $50 \%$ mais $\alpha$-tocoferol que as carnes brancas (Lin et al., 1989a). Estas diferenças na taxa de acúmulo podem ser resultantes das variações fisiológicas no sistema vascular destes tecidos, bem como no seu teor de gordura. Como o conteúdo de lipídios da carne escura é muito superior ao da carne branca, é provável que o acúmulo de $\alpha$-tocoferol também seja maior, uma vez que a vitamina E é lipossolúvel.

O papel da vitamina $E$ na manutenção da cor da carne também tem sido muito estudado. O mecanismo através do qual esta vitamina atua na manutenção da estabilidade da cor ainda não está completamente elucidado, mas sabe-se que os processos de oxidação lipídica e de descoloração da carne fresca estão intimamente ligados. A taxa de descoloração está relacionada tanto com a taxa de oxidação dos pigmentos como com o consumo de oxigênio, uma vez que baixas taxas de oxidação da mioglobina têm sido encontradas em carnes com níveis baixos de oxidação lipídica decorrentes do fornecimento de grandes quantidades de vitamina $E$ na dieta (Jensen et al., 1998). No entanto, os efeitos da suplementação de vitamina $E$ na estabilidade da cor da carne fresca são mais evidentes em espécies que apresentam altos níveis de mioglobina, como nas carnes bovina e ovina.

Os antioxidantes de quebra de cadeia (ou antioxidantes primários) são compostos que interceptam os radicais livres envolvidos no processo oxidativo. Durante este processo, são formados radicais livres do antioxidante, que são compostos estáveis e que não têm energia suficiente para reagir com os compostos lipídicos e formar novos radicais livres, quebrando a cadeia de reações. Os antioxidantes naturais como os tocoferóis e alguns óleos essenciais extraídos de algumas especiarias (orégano, alecrim, sálvia) e os 
antioxidantes artificiais convencionais como o $\mathrm{BHT}$, BHA e o propil galato fazem parte deste grupo.

Os antioxidantes supressores do oxigênio são compostos que reagem diretamente com o oxigênio e removem-no do sistema. Compostos como o ácido ascórbico e o ascorbil palmitato fazem parte deste grupo.

Alguns antioxidantes agem inibindo a fase de iniciação quelatando íons de metais que catalisam as reações de oxidação. Estes compostos restringem desta forma a formação de radicais livres e de peróxidos. Os ácidos cítrico e fosfórico pertencem a este grupo e normalmente são utilizados juntamente com os antioxidantes primários (Adams, 1999). 


\section{OXIDAÇÃO LIPÍDICA DO ÓLEO DE VÍSCERAS DE AVES REDUZ O SEU CONTEÚDO DE ENERGIA METABOLIZÁVEL PARA FRANGOS DE CORTE NA FASE DE CRESCIMENTO}

\section{Resumo}

Com a finalidade de determinar os teores de energia metabolizável aparente (EMA) e energia metabolizável aparente corrigida para o nitrogênio (EMAn) do óleo de vísceras de aves fresco e oxidado, foi conduzido um ensaio de metabolismo utilizando-se 48 frangos machos AgRoss com 31 dias de idade. As aves foram alojadas em gaiolas metabólicas e o método utilizado foi o de coleta total de excretas. Foi fornecida uma dieta referência ou essa dieta com substituição de $10 \%$ pelo óleo de vísceras de aves fresco ou oxidado, sendo que cada dieta foi oferecida a quatro repetições de quatro aves. O período de coleta foi de 4 dias após 3 dias para adaptação às dietas e às gaiolas. O óleo de vísceras de aves foi obtido de um produtor local e armazenado congelado a $-18{ }^{\circ} \mathrm{C}$ (óleo fresco). O óleo oxidado foi obtido através de aquecimento e durante esse período a sua qualidade foi monitorada através de avaliações periódicas da absorbância específica, que indica o acúmulo de compostos dienos conjugados. Os valores de absorbância específica, medidos no comprimento de onda de 232 e $270 \mathrm{~nm}$, foram, respectivamente, de 4,64 e 0,47 para o óleo fresco e de 18,54 e 3,76 para o óleo oxidado. Os resultados obtidos, e expressos na matéria original, para EMA e EMAn foram 9.240 e $9.150 \mathrm{kcal} / \mathrm{kg}$ para o óleo de vísceras fresco e 7.700 e $7.595 \mathrm{kcal} / \mathrm{kg}$ para o óleo 
oxidado, comprovando estatisticamente $(P<0,0001)$ uma grande redução no conteúdo de energia metabolizável do óleo decorrente do processo oxidativo.

\section{Summary}

Lipid oxidation decreases metabolizable energy of poultry offal fat for growing broilers

In order to determine the apparent metabolizable energy (AME) and $\mathrm{N}$-corrected apparent metabolizable energy (AMEn) of fresh and oxidized poultry offal fat a metabolism assay with 48 AgRoss male broilers from 31 to 34 days of age was conducted. The birds were fed a reference diet or this diet replaced by $10 \%$ of fresh or oxidized fat and the total excreta collection method was applied. The birds were housed in metabolic cages and each diet was supplied for four replications of four birds. Fresh poultry fat was supplied by a local renderer and then stored frozen $\left(-18^{\circ} \mathrm{C}\right)$. The oxidized poultry fat was obtained by heating $\left(80-90{ }^{\circ} \mathrm{C}\right)$ and specific absorbances were measured frequently to control fat quality. Specific absorbances at 232 and $270 \mathrm{~nm}$ were, respectively, 4.64 and 0.47 for fresh fat and 18.54 and 3.76 for oxidized fat, which suggest higher levels of oxidation compounds in the oxidized poultry fat. The results of AME and AMEn were 9,240 and 9,150 kcal/kg (as fed-basis) for the fresh poultry fat and 7,770 and 7,595 kcal/kg (as fed-basis) for the oxidized poultry fat. The differences in energy content were significant $(P<0.0001)$, indicating a decrease in the metabolizable energy from the fresh poultry fat to the oxidized fat due to oxidation. 


\subsection{Introdução}

Óleos e gorduras são ingredientes muito utilizados nas rações como fonte concentrada de energia, permitindo a formulação de dietas de alta energia para frangos de corte. A indústria avícola tem utilizado em larga escala subprodutos de abatedouros adicionados às rações, como o óleo de vísceras de aves, que tem como principal vantagem o baixo custo, bem como o alto conteúdo energético (9.360 kcal/kg, de acordo com o NRC, 1994). No entanto, o perfil de ácidos graxos deste óleo favorece o desenvolvimento da rancidez oxidativa devido à grande quantidade de ácidos graxos insaturados, principalmente os ácidos oléico e linoléico.

Estes ácidos graxos insaturados são facilmente oxidados devido à presença de duplas ligações nas cadeias de carbono da sua estrutura química (Robey \& Shermer, 1994). De acordo com o NRC (1994), os ácidos oléico e linoléico representam, juntos, 69,50\% do total de gordura deste óleo.

Segundo Scott (1982), o processo de oxidação lipídica é a principal causa da perda de qualidade do alimento ou da ração, afetando seu sabor, aroma, cor e textura, além de resultar na produção de compostos tóxicos e num sério decréscimo do seu valor nutritivo.

A redução no desempenho, seja no ganho de peso ou conversão alimentar identificada em estudos com aves submetidas a estresse oxidativo (Cabel et al., 1988; Lin et al., 1989a; Engberg et al., 1996) decorre, provavelmente, da presença dos compostos de ranço e da redução do conteúdo energético e impalatabilidade do alimento oxidado aliados à baixa eficiência da sua utilização pelos animais.

O principal objetivo deste estudo foi quantificar esta redução da EMA e EMAn do óleo de vísceras de aves em conseqüência da sua oxidação, além de gerar informações no que diz respeito à real suscetibilidade desta matéria-prima à oxidação e à utilização de metodologias de análise para o acompanhamento da sua qualidade durante o processo oxidativo. 


\subsection{Material e Métodos}

Durante os meses de agosto a dezembro de 2001 foi conduzido o ensaio experimental nas instalações do Departamento de Zootecnia e no Departamento de Agroindústria, Alimentos e Nutrição, da Escola Superior de Agricultura "Luiz de Queiroz", em Piracicaba/SP. A oxidação do óleo de vísceras de aves, bem como as análises de acompanhamento da qualidade deste óleo foram conduzidas no Laboratório de Óleos e Gorduras do Departamento de Agroindústria, Alimentos e Nutrição.

O óleo de vísceras de aves foi obtido de um fornecedor regional, sendo produzido sem a adição de nenhum antioxidante. Uma parte deste óleo foi mantida congelada $\left(-18^{\circ} \mathrm{C}\right)$ desde a sua extração até a mistura nas rações, sendo este tratamento denominado óleo fresco. No recebimento do lote foi retirada uma amostra que foi destinada às análises de determinação da sua composição e para assegurar que este produto se apresentava livre de compostos de ranço (amostra inicial). Uma outra parte do óleo foi oxidada (tratamento oxidado) através do aquecimento intermitente com temperatura em torno de 80 a $90{ }^{\circ} \mathrm{C}$ em banho-maria com constante aeração por um período de 40 dias.

Diariamente, durante todo o processo de oxidação do óleo, foram coletadas amostras para acompanhamento da oxidação. Nestas amostras foram efetuadas determinações de Índice de Peróxidos conforme metodologia descrita no COMPÊNDIO (1998), no entanto, este método mostrou-se pouco eficiente para o acompanhamento da oxidação do óleo sob termoxidação por um período prolongado. Por este motivo, foram quantificados também os produtos da oxidação (dienos e trienos) através do método espectrofotométrico IUPAC número II.D.23 (1979). Este método analítico permite determinar a absorbância do óleo em determinados comprimentos de onda do espectro ultravioleta e fornece uma indicação do seu grau de oxidação. Isso porque os produtos da oxidação se apresentam em espectros característicos na região ultravioleta, os dienos em $232 \mathrm{~nm}$ e os trienos ou compostos secundários em 
$270 \mathrm{~nm}$. De uma forma geral, a determinação da absorbância específica a 232 $\mathrm{nm}$ e a $270 \mathrm{~nm}$ pode fornecer um indicativo do estado de oxidação do óleo através da revelação da presença de seus compostos secundários (White, 1995).

As rações experimentais foram fabricadas nas instalações experimentais do Departamento de Zootecnia, assim como a criação dos animais experimentais (machos de um dia da linhagem comercial AgRoss). Nesta fase que antecedeu o ensaio de metabolismo, os animais foram alimentados à vontade, com ração à base de milho e farelo de soja com 3.050 $\mathrm{kcal} / \mathrm{kg}$ de energia e $21,5 \%$ de proteína bruta.

Aos 28 dias de idade, 48 animais foram transferidos para uma sala climatizada contendo uma bateria de 12 gaiolas metabólicas, marca Petersime. As unidades experimentais foram representadas pelas gaiolas, que tinham 0,70 $\mathrm{m}$ de comprimento por 0,66 $\mathrm{m}$ de largura e $0,34 \mathrm{~m}$ de altura e abrigaram quatro aves com peso médio de $1,2 \mathrm{~kg}$ recebendo ração e água à vontade durante todo período experimental. O período de adaptação às gaiolas e à dieta foi de três dias, os quais antecederam os quatro dias de coleta das excretas. O início e o final do período de coleta foram definidos através do fornecimento de ração marcada com óxido de ferro e do aparecimento das excretas pigmentadas.

Utilizou-se uma ração referência (Tabela 1) formulada à base de milho e farelo de soja de acordo com as exigências das aves na fase de crescimento (Rostagno, 2000), e duas rações teste obtidas pela substituição da ração referência por $10 \%$ do óleo de vísceras de aves fresco ou oxidado, que representaram os dois tratamentos estudados. Cada tratamento (dieta referência, dieta referência $+10 \%$ óleo de vísceras fresco e dieta referência + 10\% óleo de vísceras oxidado) foi aplicado a quatro repetições, portanto, a quatro gaiolas contendo quatro aves por gaiola. $O$ delineamento experimental foi inteiramente casualizado. A mistura dos óleos e preparo das rações experimentais foi feita imediatamente antes do início do experimento e as 
rações foram mantidas na sala climatizada com temperatura média entre 25 e $28^{\circ} \mathrm{C}$, juntamente com as aves.

Tabela 1. Composição percentual da ração referência e níveis calculados dos nutrientes

\begin{tabular}{lc}
\hline Ingredientes & $\%$ \\
\hline Milho & 67,320 \\
Farelo de Soja 45,5\% & 28,730 \\
Fosfato Bicálcico & 1,630 \\
Calcário Calcítico & 1,260 \\
Sal & 0,500 \\
Suplemento Vitamínico ${ }^{1}$ & 0,300 \\
Suplemento Mineral ${ }^{2}$ & 0,050 \\
DL-Metionina & 0,111 \\
L-Lisina.HCl & 0,105 \\
& \\
EMA kcal/kg & Níveis Calculados \\
PB \% & 2.930 \\
Extrato Etéreo \% & 19,00 \\
Metionina \% & 2,730 \\
Met + Cis \% & 0,410 \\
Lisina \% & 0,760 \\
Cálcio \% & 1,050 \\
Fósforo Disponível \% & 1,000 \\
\hline
\end{tabular}

${ }^{1}$ Concentração por kg de ração: ácido fólico, 0,999 mg; ácido pantotênico, 15,00 mg; BHT, 22,5 mg; biotina, 0,06 mg; colina, 399 mg; niacina, 40 mg; selênio, 0,3 mg; vit. A, 7.998,00 Ul; vit. $D_{3}$, $1,998 \mathrm{Ul}$; vit. E, $15 \mathrm{UI}$; vit. K, 1,8 mg; tiamina, 1,8 mg; riboflavina, 6,0 mg; piridoxina, 2,8 mg; vit. $\mathrm{B}_{12}, 12 \mathrm{mcg}$; olaquindox, $40 \mathrm{mg}$; avilamicina, $5 \mathrm{mg}$; salinomicina, $66 \mathrm{mg}$; acido 3-nitro, $35 \mathrm{mg}$.

${ }^{2}$ Concentração por kg de ração: manganês, 75 mg; zinco, 50 mg; ferro, 50 mg; cobre, 8 mg; iodo, $0,75 \mathrm{mg}$. 
O período de coleta de excretas foi do $31^{\circ}$ ao $34^{\circ}$ dias de criação das aves, sendo a coleta efetuada duas vezes ao dia. No momento da coleta tomou-se o devido cuidado para coletar todo conteúdo de excretas eliminado no período, evitando-se o excesso de contaminação com penas ou ração.

As amostras de rações e a totalidade das excretas coletadas foram armazenadas em congelador até o momento da pesagem, quando foram descongeladas e homogeneizadas. Neste momento foi retirada uma amostra representativa de cada repetição para a pré-secagem, que foi feita em estufa de circulação forçada a $65{ }^{\circ} \mathrm{C}$ por $72 \mathrm{~h}$. Em seguida, as amostras foram moídas para determinações de umidade total, nitrogênio, extrato etéreo e proteína bruta. As amostras de rações e excretas foram analisadas em laboratório particular (CBO Assessoria \& Análise, em Campinas/SP).

As determinações de energia bruta das amostras das rações e das excretas foram feitas no Laboratório de Bromatologia do Departamento de Zootecnia utilizando-se a bomba calorimétrica Parr modelo 1261 e foi utilizada a metodologia de Matterson et al. (1965) para o cálculo da EMA e EMAn.

Os valores de EMA e EMAn médios obtidos para os dois tratamentos (óleo fresco e óleo oxidado) foram comparados utilizando-se o teste $t$, através dos procedimentos do Sistema SAS (1996).

\subsection{Resultados e Discussão}

Os resultados das análises efetuadas no óleo de vísceras de aves fresco e oxidado estão apresentados nas Tabelas 2 e 3. Durante o processo de oxidação do óleo foram percebidas modificações em certos aspectos físicos, a cor se tornou mais escura, o odor e a viscosidade diminuíram sensivelmente. Quanto às características químicas, nota-se na Tabela 2 que os teores de umidade, acidez, índice de peróxidos são mais elevados para o óleo oxidado, entretanto, a presença de compostos decorrentes da oxidação através das 
absorbâncias específicas é que efetivamente caracteriza o estado oxidativo do ingrediente.

Tabela 2. Caracterização do óleo de vísceras fresco e oxidado no momento de sua incorporação nas rações

\begin{tabular}{lccc}
\hline Análises & Unidades & Óleo Fresco & Óleo Oxidado \\
\hline Umidade $^{1}$ & $\%$ & 0,04 & 0,27 \\
Acidez $^{1}$ & $\mathrm{mg} \mathrm{KOH/g}$ & 1,49 & 4,24 \\
Extrato Etéreo $^{1}$ & $\%$ & 99,51 & 99,85 \\
Índice de Peróxidos $^{1}$ & meq peróxidos/kg & 0,78 & 4,17 \\
Absorbância específica & & \\
\multicolumn{2}{c}{$232 \mathrm{~nm}$} & 4,64 & 18,54 \\
$270 \mathrm{~nm}$ & 0,47 & 3,76
\end{tabular}

${ }^{1}$ Análises realizadas no Laboratório CBO Assessoria \& Análise, Campinas/SP.

Os resultados de absorbância específica do óleo de vísceras mantido fresco foram baixos (4,64 e 0,47 em 232 e $270 \mathrm{~nm}$, respectivamente) indicando pequena quantidade de compostos primários e secundários de ranço, enquanto que no óleo oxidado as absorbâncias específicas foram bem mais elevadas (18,54 e 3,76 em 232 e $270 \mathrm{~nm}$, respectivamente), o que revela um adiantado estado oxidativo. Absorbâncias específicas bem mais baixas $(4,40$ e 0,83 em 232 e $270 \mathrm{~nm}$, respectivamente) foram obtidas por Bou et al. (2001) e Grau et al. (2001), quando promoveram a oxidação em óleo de girassol.

Informações também interessantes são fornecidas pela análise do perfil dos ácidos graxos presentes nos óleos utilizados neste estudo. Como pode ser verificado na Tabela 3, houve uma alteração no perfil das amostras analisadas após a oxidação. De uma maneira geral, houve um ligeiro aumento nos teores dos ácidos graxos, exceto os ácidos linoléico (C18:2) e linolênico (C18:3), que apresentaram reduções no óleo oxidado. Resultados semelhantes foram encontrados por Sheehy et al. (1994) e Engberg et al. (1996) quando 
promoveram a oxidação em óleos vegetais. Esta tendência de redução dos ácidos graxos com duplas ligações em suas moléculas é resultante da sua degradação decorrente do processo oxidativo a que o óleo foi submetido.

Tabela 3. Perfil de ácidos graxos do óleo de vísceras de aves fresco e oxidado

\begin{tabular}{lcc}
\hline Ácidos Graxos (\%) & Óleo Fresco & Óleo Oxidado \\
\hline Ác. mirístico (C14:0) & 0,67 & 0,83 \\
Ác. palmítico (C16:0) & 22,35 & 25,25 \\
Ác. palmitoléico (C16:1) & 8,95 & 9,83 \\
Ác. esteárico (C18:0) & 5,17 & 5,56 \\
Ác. oléico (C18:1) & 43,73 & 45,93 \\
Ác. linoléico (C18:2) & 17,33 & 12,61 \\
Ác. linolênico (C18:3) & 0,90 & - \\
Ác. araquidônico (C20:4) & 0,41 & - \\
Ác. gadoléico (C20:1) & 0,52 & - \\
Total Saturados & 28,60 & 31,64 \\
Total Insaturados & 71,43 & 68,37
\end{tabular}

${ }^{1}$ Análises realizadas no Laboratório de Óleos e Gorduras da FEA - UNICAMP, Campinas/SP, em Cromatógrafo Gasoso Capilar - Perkin Elmer 8420. Método AOCS Ce 2-66 - com BF 3

$\mathrm{Na}$ Tabela 4, encontram-se os resultados obtidos no ensaio de metabolismo para EMA e EMAn referentes ao óleo fresco e ao oxidado. Os teores de EMA e EMAn obtidos para o óleo fresco (9.240 e $9.150 \mathrm{kcal} / \mathrm{kg}$ ) estão em conformidade com o valor apresentado pelo NRC (1994), EMV de 9.360 $\mathrm{kcal} / \mathrm{kg}$, assim como a composição do óleo em ácidos graxos.

Já a comparação dos resultados de EMA e EMAn para o óleo oxidado torna-se muito difícil devido à escassez de resultados publicados. Pode-se afirmar, contudo, que houve um efeito acentuado do estado oxidativo do óleo de vísceras de aves sobre os teores de energia obtidos, refletindo numa redução de cerca de 17\% nos valores de EMA e de EMAn do óleo oxidado em 
relação ao mesmo ingrediente mantido fresco. Alguns autores afirmam que os efeitos negativos do óleo oxidado fornecido na dieta se devem a sua menor palatabilidade e, conseqüentemente o menor consumo por parte dos animais. Contudo, apesar da alta inclusão de óleo nas rações teste deste estudo, nenhuma redução foi verificada no consumo de ração do tratamento com óleo oxidado (460 g/ave) em relação ao óleo fresco (455 g/ave) nos 4 dias do ensaio.

Tabela 4. Resultados de Energia Metabolizável Aparente (EMA) e corrigida para o Nitrogênio (EMAn) para o óleo de vísceras de aves fresco e oxidado Ingrediente EMA EMAn

$(\mathrm{kcal} / \mathrm{kg})$

\begin{tabular}{lll}
\hline Óleo Fresco & $9.240^{\mathrm{a}} \pm 317$ & $9.150^{\mathrm{a}} \pm 278$ \\
Óleo Oxidado & $7.770^{\mathrm{b}} \pm 132$ & $7.595^{\mathrm{b}} \pm 108$
\end{tabular}

${ }^{a, b}$ Médias na mesma coluna diferem estatisticamente $(P<0,0001)$ pelo teste $t$.

Por outro lado, de acordo com Engberg et al. (1996), dependendo da origem do óleo e das condições a que ele foi submetido durante a oxidação (temperatura e duração do aquecimento, adição de oxigênio e catalisadores, e atividade de água) pode ser formada uma grande variedade de compostos de ranço quimicamente diferentes durante a oxidação. Acredita-se que muitos destes compostos apresentem efeitos tóxicos no organismo, provocando danos às células epiteliais do intestino e ao fígado, prejudicando a absorção e o aproveitamento do óleo oxidado. Talvez a presença de grande quantidade destes compostos de ranço no óleo oxidado (Tabela 2) seja a principal causa da redução dos valores energéticos obtidos neste ensaio.

Os efeitos negativos do fornecimento do óleo oxidado na dieta sobre o desempenho de frangos de corte já foram muitas vezes demonstrados (Cabel et al., 1988; Lin et al., 1989a; Sheehy et al., 1994, Engberg et al., 1996) 
e acredita-se que a depressão do crescimento pode ser devido à presença dos produtos da oxidação, que levam a valores reduzidos de energia da dieta pelo decréscimo do valor biológico do ingrediente oxidado. Os resultados obtidos neste estudo confirmam este fato, e estão de acordo com Engberg et al. (1996), uma vez que os valores de EMA e EMAn foram significativamente inferiores $(P<0,0001)$ para o óleo de vísceras de aves submetido à oxidação.

\subsection{Conclusões}

O processo de oxidação lipídica provocou alterações nas características físicas e químicas do óleo de vísceras de aves. Estas alterações refletiram-se no valor biológico do óleo quando fornecido a frangos de corte na fase de crescimento, já que os teores de EMA e de EMAn foram, em média, $17 \%$ inferiores para o óleo oxidado. 


\section{EFEITOS DO ÓLEO DE VÍSCERAS DE AVES OXIDADO NA RAÇÃO NO DESEMPENHO DE FRANGOS DE CORTE E NA ESTABILIDADE OXIDATIVA DA CARNE DE SOBRECOXA ARMAZENADA SOB REFRIGERAÇÃO}

\section{Resumo}

Com a finalidade de avaliar o efeito do uso do óleo de vísceras de aves oxidado na ração sobre o desempenho de frangos de corte e a estabilidade oxidativa da carne das aves, foi conduzido um experimento utilizando-se 160 pintos machos de um dia da linhagem Cobb. Os animais consumiram rações contendo $4 \%$ de óleo fresco ou oxidado, dos 10 aos 47 dias

de idade, à vontade. $\mathrm{O}$ óleo fresco foi congelado $\left(-18{ }^{\circ} \mathrm{C}\right)$ desde o momento do recebimento do lote até o uso. O óleo foi oxidado através do aquecimento (110 a $120{ }^{\circ} \mathrm{C}$ ) em fritadeira elétrica por 21 dias, até atingir absorbâncias específicas de 10,52 a $232 \mathrm{~nm}$ e 1,97 a $270 \mathrm{~nm}$. Os animais foram abatidos aos 47 dias de idade, quando foram feitas avaliações de rendimento de carcaça e das partes, além da porcentagem de gordura abdominal. As amostras de sobrecoxa foram desossadas e mantidas refrigeradas (temperaturas entre 0,7 a $4,8{ }^{\circ} \mathrm{C}$ ) por 12 dias para análises periódicas e avaliação da sua qualidade. O óleo oxidado não influenciou o desempenho das aves, nem tampouco o rendimento da carcaça e das partes. Após 12 dias de armazenamento refrigerado da carne de sobrecoxa, os valores de $L^{*}$ não apresentaram diferenças, mas os resultados de TBARS (mg malonaldeídos/kg de amostra) foram, em média, superiores 
$(P=0,0016)$ para o tratamento com óleo oxidado, comprovando os efeitos negativos do consumo de alimento oxidado sobre a estabilidade da carne.

\section{Summary}

The effects of dietary oxidized poultry offal fat on broiler perfomance and oxidative stability of chilled thigh meat

An experiment was conducted to evaluate the effects of dietary oxidized poultry offal fat on the performance of broiler chickens and on the oxidative stability of chilled dark meat. One hundred and sixty Cobb male chicks were fed a corn-soy diet containing $4 \%$ fresh or oxidized poultry fat from 10 to 47 days of age. Fresh poultry fat was supplied by a local renderer and then stored frozen $\left(-18{ }^{\circ} \mathrm{C}\right)$ until diets were produced. Oxidized fat (specific absorbances were 10.52 and 1.97 at 232 and $270 \mathrm{~nm}$, respectively) was obtained by heating ( 110 to $120^{\circ} \mathrm{C}$ ) in a fryer for 21 days. Birds were slaughtered at 47 days of age when carcass characteristics and abdominal fat were measured. Skinless and deboned raw thigh meat was stored chilled (0.7 to $4.8^{\circ} \mathrm{C}$ ) during 12 days and samples were collected periodically to assess its quality and stability. Dietary oxidized poultry fat did not affect bird performance or carcass characteristics. During chill storage color was not affected and L* values were high for both treatments. TBARS values were higher $(P=0.0016)$ in thigh meat from chickens fed the oxidized fat, indicating lower oxidative stability. 


\subsection{Introdução}

A oxidação lipídica em carnes é considerada a principal causa da perda de qualidade e de suas propriedades sensoriais, tais como odor, sabor, textura, valor nutritivo, além de segurança alimentar (Buckley et al., 1995; Gray et al., 1996; Jensen et al., 1998). A ocorrência e a evolução do processo oxidativo nas carnes são influenciadas por muitos fatores como o teor de gordura e o perfil de ácidos graxos na carne, grau de processamento (desossa, moagem, aquecimento), condições de armazenamento (tempo, temperatura, embalagem) e a proporção de agentes pró-oxidantes (ferro, mioglobina) e antioxidantes presentes no tecido, de acordo com Jensen et al. (1997).

Alguns estudos têm indicado que o potencial oxidativo dos tecidos musculares é diferente para as várias espécies, sendo a carne de frangos bastante suscetível, especialmente após cozimento (Rhee et al., 1996). No caso de frangos, comparando-se as carnes brancas e escuras, a carne da sobrecoxa é a que apresenta maior suscetibilidade à oxidação em relação ao peito (Jensen et al., 1998). Por outro lado, as recentes recomendações de consumo de alimentos com menos gorduras saturadas têm levado a um aumento na procura de produtos com altos teores de ácidos graxos insaturados. No entanto, estes alimentos são também altamente suscetíveis à oxidação lipídica e ao desenvolvimento de "off-flavor" (Buckley et al., 1995).

Acredita-se que o processo de oxidação lipídica se inicie na fração fosfolipídica altamente insaturada da membrana celular, imediatamente após o abate. Neste momento, ocorrem mudanças bioquímicas que favorecem o processo da oxidação lipídica, uma vez que há um desbalanço entre os fatores pró-oxidantes e a capacidade antioxidante, em favor da oxidação (Buckley et al., 1995; Gray et al., 1996; Morrissey et al., 1998). Imediatamente após o abate ainda existe uma certa atividade metabólica, no entanto, devido à falta de circulação do sangue, os produtos da quebra do glicogênio se acumulam nos tecidos na forma de ácido lático. Esse acúmulo leva a uma redução gradual do pH a níveis levemente ácidos (cerca de 5,5), mas variáveis para os diferentes 
tecidos. Além disso, o sistema de defesa antioxidante (superóxido dismutase, glutationa peroxidase, transferrina) pode estar enfraquecido devido a deficiências de retinol, vitaminas C e E, e de carotenóides da dieta, e é improvável que este sistema normalmente disponível no animal vivo ainda funcione (Buckley et al, 1995).

Os efeitos do consumo de alimentos oxidados por frangos de corte têm sido muito estudados, sendo evidentes os prejuízos no desempenho dos animais (Waldroup et al., 1960; Cabel et al., 1988; Asghar et al., 1989; Lin et al., 1989b; Sheehy et al., 1994; Engberg et al., 1996), na estabilidade oxidativa dos tecidos decorrente da redução da concentração de $\alpha$-tocoferol presente nas membranas celulares (Asghar et al., 1989; Lin et al., 1989a; Jensen et al., 1997; Jensen et al., 1998; Grau et al., 2001b) e, conseqüentemente, no tempo de prateleira das carnes durante o armazenamento (Sheehy et al., 1994; Rhee et al., 1996; Jensen et al., 1997; Sheldon et al., 1997; Grau et al., 2001a).

Sendo assim, o objetivo deste estudo foi avaliar o desempenho de frangos de corte até 42 dias, aspectos do rendimento da carcaça, das partes e da carne, além de estudar a estabilidade oxidativa da carne da sobrecoxa, refrigerada durante 12 dias, das aves alimentadas com rações contendo óleo de vísceras de aves fresco ou oxidado.

\subsection{Material e Métodos}

\subsection{1 Óleo de vísceras de aves}

No início do mês de maio/2002 foi recebido um lote fresco de 70 $\mathrm{kg}$ de óleo de vísceras de aves proveniente de um fornecedor regional, e produzido sem a adição de antioxidante. Deste lote foi retirada uma amostra para avaliação da qualidade e composição iniciais do produto. Uma parte deste óleo (cerca de $35 \mathrm{~kg}$ ), imediatamente após o recebimento, foi acondicionada em embalagens plásticas e armazenada em congelador à temperatura de $-18{ }^{\circ} \mathrm{C}$, 
para a manutenção das suas características originais. Este foi considerado o óleo de vísceras fresco.

O processo de oxidação dos $35 \mathrm{~kg}$ restantes do óleo de vísceras de aves foi conduzido no Laboratório de Óleos e Gorduras do Departamento de Agroindústria, Alimentos e Nutrição, da ESALQ/USP. Para aceleração do processo de oxidação foi feito aquecimento em uma fritadeira elétrica Tedesco, modelo FAO-30. O equipamento era ligado pela manhã (7:30h) e desligado à tarde (18:00h), ficando o óleo sob aquecimento (com temperaturas entre $110 \mathrm{e}$ $120^{\circ} \mathrm{C}$ ) durante todo o dia, por 21 dias consecutivos. Para acelerar o processo, durante todas as noites o óleo era transferido para recipientes de vidro abertos e de grande superfície de exposição que eram colocados na câmara de fotoxidação. Nesta câmara, a oxidação era promovida pelo uso de lâmpadas fluorescentes colocadas a cerca de $30 \mathrm{~cm}$ da superfície do óleo.

Durante o período de oxidação do óleo foram retiradas amostras periodicamente para quantificação de produtos da oxidação (dienos e trienos) presentes no óleo, acompanhando, assim, o estado oxidativo do ingrediente. O método utilizado foi o IUPAC número II.D.23 (1979), que determina a absorbância do óleo no espectro ultravioleta e fornece uma indicação do seu grau de deterioração decorrente da oxidação lipídica. Tais análises foram realizadas no Laboratório de Óleos e Gorduras do Departamento de Agroindústria, Alimentos e Nutrição da ESALQ/USP.

\subsubsection{Ensaio de Desempenho}

Foram utilizados 160 pintos de um dia, machos, da linhagem Cobb, alojados em galpão experimental do Departamento de Zootecnia da ESALQ/USP. Os animais foram divididos em dois tratamentos com quatro boxes cada, sendo 20 aves por box (unidade experimental), em delineamento inteiramente casualizado.

Durante os primeiros dias de vida as aves foram alojadas em círculo de proteção com aquecimento feito através de campânula a gás. 
Somente após os 10 dias de idade as aves foram transferidas para os boxes, quando foram aplicados os tratamentos e passaram a consumir a dieta contendo $4 \%$ de óleo de vísceras de aves fresco ou oxidado.

A ração foi formulada para atender às exigências das aves dos 10 dias até o abate (fase única, Tabela 1) de acordo com Rostagno (2000). As aves receberam ração e água à vontade e luz natural.

Tabela 1. Composição percentual da ração experimental e níveis calculados dos nutrientes

\begin{tabular}{lc}
\hline Ingredientes & $\%$ \\
\hline Milho & 60,00 \\
Farelo de Soja 45,5\% PB & 32,00 \\
Óleo de vísceras de aves $^{1}$ & 4,00 \\
Fosfato Bicálcico & 1,70 \\
Calcário Calcítico & 1,00 \\
Sal & 0,500 \\
Suplemento Vitamínico ${ }^{2}$ & 0,300 \\
Suplemento Mineral & \\
DL-Metionina & 0,050 \\
L-Lisina.HCl & 0,250 \\
& 0,260 \\
EMA kcal/kg & \\
PB \% $\%$ cíveis calculados & 3.153 \\
Extrato Etéreo \% & 20,00 \\
Metionina \% & 6,50 \\
Met + Cis \% & 0,553 \\
Lisina \% & 0,870 \\
Cálcio \% & 1,240 \\
Fósforo disponível \% & 0,950 \\
T & 0,430
\end{tabular}

${ }^{1}$ Tratamentos: substituição pelo óleo fresco ou oxidado.

${ }^{2}$ Concentração por $\mathrm{kg}$ de ração: ácido fólico, 0,999 mg; ácido pantotênico, $15 \mathrm{mg}$; BHT, 22,5 mg; biotina, 0,06 mg; colina, 339 mg; niacina, 40 mg; selênio, 0,3 mg; vit. A, 7.998,00 Ul; vit. $D_{3}$, 1,998 Ul; vit. E, 15 Ul; vit. K, 1,8 mg; tiamina, 1,8 mg; riboflavina, 6,0 mg; piridoxina, 2,8 mg; vit. $\mathrm{B}_{12} 12 \mathrm{mcg}$; olaquindox $40 \mathrm{mg}$; avilamicina $5 \mathrm{mg}$; nicarbazina $110 \mathrm{mg}$.

${ }^{3}$ Concentração por kg de ração: manganês, 75 mg; zinco, 50 mg; ferro, 50 mg; cobre, 8 mg; iodo, $0,75 \mathrm{mg}$. 
Semanalmente foram feitas pesagens das aves e da ração para determinação do peso vivo, ganho de peso e consumo de ração no período. O ensaio de desempenho foi encerrado aos 42 dias de idade das aves, quando foi efetuada a última pesagem dos animais e da ração. Além disso, os animais também foram pesados individualmente e cada ave foi identificada com uma anilha numerada em uma das patas.

\subsubsection{Abate e ensaio de armazenamento refrigerado}

As aves continuaram consumindo a ração dos respectivos tratamentos e aos 47 dias de idade, 120 aves (60 de cada tratamento, 15 por unidade experimental) foram abatidas no abatedouro experimental da Faculdade de Medicina Veterinária e Zootecnia da UNESP, em Botucatu/SP. As aves foram transportadas em engradados de plástico (oito aves por caixa) durante a madrugada. Os animais foram pesados individualmente na plataforma de recebimento, logo depois foram atordoados, abatidos, escaldados e depenados. Em seguida, foi feita a evisceração, sendo separada a porção de gordura abdominal. Neste momento, a carcaça eviscerada, sem cabeça, pés e pescoço, foi novamente pesada para o cálculo do rendimento.

Na seqüência, foi feita a separação de partes (peito e pernas), e foram pesados o peito e as pernas inteiras, além da gordura abdominal. Em seguida, foram desossados peito e sobrecoxa. O peso da carne do peito e da sobrecoxa permitiu o cálculo do rendimento em carne destas partes. A carne da sobrecoxa foi acondicionada em sacos plásticos e mantida em caixa de isopor com gelo durante o abate e o transporte, até o momento da embalagem e armazenamento.

A embalagem e o armazenamento foram feitos no mesmo dia do abate na Planta Piloto e no Laboratório de Óleos e Gorduras do Departamento de Agroindústria, Alimentos e Nutrição da ESALQ/USP. Oito sobrecoxas desossadas de cada repetição foram embaladas em duas bandejas de 
poliestireno revestidas com filme plástico de PVC, devidamente identificadas e armazenadas em refrigerador apropriado. As temperaturas mínimas e máximas foram medidas diariamente e tiveram médias de 0,7 a $4,8^{\circ} \mathrm{C}$, respectivamente.

As bandejas contendo as amostras de carne foram armazenadas durante 12 dias, sendo que as análises foram efetuadas nos dias um, quatro, oito e 12 de armazenamento.

\subsubsection{Análises químicas da carne de frango}

As análises químicas da carne de sobrecoxa foram realizadas no Laboratório de Óleos e Gorduras do Departamento de Agroindústria, Alimentos e Nutrição da ESALQ/USP, através das determinações de gordura, proteína bruta, umidade, matéria mineral, carboidratos totais (por diferença), e pH. As análises de TBARS e cor foram executadas no Laboratório de Irradiação de Alimentos, no Centro de Energia Nuclear na Agricultura (CENA), em Piracicaba/SP. O perfil dos ácidos graxos, lipídios totais e colesterol total das amostras de óleo e da carne de sobrecoxa foram efetuados na Faculdade de Saúde Pública da USP, em São Paulo/SP.

\subsubsection{Composição centesimal}

As carnes de frango foram caracterizadas através de sua composição em gordura e proteína bruta, de acordo com a AOCS (1990), pelo teor de umidade e de matéria mineral, segundo AOAC (1995), e os carboidratos totais foram calculados pela diferença. Tais análises foram executadas em duplicata em três amostras de cada tratamento, somente nas amostras iniciais, no primeiro dia do experimento.

\subsubsection{2 $\mathrm{pH}$}

$\mathrm{O} \mathrm{pH}$ foi determinado com um potenciômetro em uma mistura de partes iguais, de amostra e de água bidestilada, após homogeneização em um processador de alimentos. As determinações foram realizadas em duplicata em 
três amostras de cada tratamento 24 horas após o abate e nos dias quatro, oito e 12 de armazenamento.

\subsubsection{Cor}

A cor foi determinada na parte dorsal do músculo, através de três leituras em três amostras inteiras de sobrecoxa para cada tratamento estudado, utilizando-se o colorímetro Chroma meter - 200b da marca MINOLTA, pelo sistema $L^{*}$ (luminosidade), $a^{*}$ croma variando do vermelho $(+)$ ao verde (-) e b* croma variando do amarelo (+) ao azul (-). As determinações foram efetuadas nos dias um, quatro, oito e 12 de armazenamento.

\subsubsection{TBARS (Thiobarbituric acid reactive substances)}

As análises de TBARS foram determinadas em duplicata em três amostras de cada tratamento nos dias um, quatro, oito e 12 de armazenamento, segundo a metodologia de Tarladgis et al. (1960). Os produtos primários da oxidação lipídica constituem-se principalmente de hidroperóxidos, que são rapidamente decompostos em várias substâncias reativas ao ácido 2tiobarbitúrico (TBA), sendo o malonaldeído o elemento mais importante. O produto da reação destes compostos secundários com o TBA é colorido e absorve fortemente a $532 \mathrm{~nm}$.

O padrão utilizado nesta reação é o 1,1',3,3" tetraetoxipropano (TEP), cuja hidrólise ácida gera malonaldeído na proporção de 1:1 mol. Desta forma, é possível expressar os resultados em "valor TBARS" (thiobarbituric acid reactive substances), expresso em $\mathrm{mg}$ de malonaldeído/1000g de amostra.

Para execução da análise, as amostras das sobrecoxas foram picadas e $100 \mathrm{~g}$ foram pesadas e homogeneizadas em um processador de alimentos com $10 \mathrm{~mL}$ de solução de BHT diluído em etanol (na concentração de $1 \mathrm{mg} / \mathrm{mL}$ ), para que a amostra não sofresse oxidação durante o preparo. Foram pesados $10 \mathrm{~g}$ de cada amostra (em duplicata) em balões volumétricos de $250 \mathrm{~mL}$. Em seguida foram adicionados de $96,5 \mathrm{~mL}$ de água destilada, 2,5 mL 
de ácido clorídrico $4 \mathrm{~N}, 1 \mathrm{~mL}$ de BHT em etanol, algumas gotas de antiespumante e contas de vidro e dado início à destilação.

O líquido destilado, cerca de $50 \mathrm{~mL}$, foi recolhido em um copo de vidro (bequer). Três mililitros deste destilado foram pipetados e transferidos para um tubo de ensaio com tampa, no qual foram adicionados outros $3 \mathrm{~mL}$ de TBA. Em seguida, as amostras foram colocadas em banho-maria a $100^{\circ} \mathrm{C}$ por 20 minutos, seguido pelas leituras em espectrofotômetro a $532 \mathrm{~nm}$.

Para a elaboração da curva padrão, as amostras de sobrecoxa de frango alimentados com óleo fresco foram preparadas da mesma forma citada anteriormente, sendo utilizadas diferentes quantidades $(0,0 ; 0,5 ; 1,0 ; 2,0 ; 5,0$; 8,0 e 10,0 mL) de 1,1', 3,3" Tetraetoxipropano (TEP), 2,5 mL de ácido clorídrico, 1,0 mL de BHT e 96,5, 96,0, 95,5, 94,5, 91,5, 88,5, 86,5 mL de água destilada, respectivamente, conforme as quantidades de TEP utilizadas. Foram preparados também, balões sem amostras com as mesmas concentrações de TEP, ácido clorídrico e BHT, e 106,5, 106,0, 105,5, 104,5, 101,5, 98,5 e 96,5mL de água destilada.

O teor de malonaldeído na amostra ( $\mu \mathrm{g}$ de malonaldeído $/ \mathrm{mL}$ do destilado) foi calculado utilizando-se a equação da curva padrão sem amostra e, em seguida, utilizou-se a seguinte fórmula para obtenção do resultado em $\mathrm{mg}$ malonaldeído/1000 g de amostra:

$\mathrm{mg}$ de malonaldeído $/ 1000 \mathrm{~g}=\underline{\mu \mathrm{g}}$ de malonaldeído $/ \mathrm{mL} \times 50 \times 1000 \times 100$

$A \times B \times 1000$

Em que:
A: peso da amostra
B: \% de recuperação do padrão 


\subsubsection{Perfil de ácidos graxos e colesterol total}

A extração dos lipídios totais da carne de sobrecoxa foi efetuada de acordo com metodologia descrita por Marmer \& Maxwell (1981). Os lipídios foram extraídos de três amostras de cada tratamento de acordo com o método proposto por Chen \& Chen (1994) e injetados em Cromatógrafo líquido de alta precisão (HPLC).

\subsubsection{Análise Estatística}

Para avaliar os efeitos dos dois tratamentos estudados (óleo fresco ou oxidado) em relação aos parâmetros observados foi utilizado o teste $\mathrm{t}$ para comparação das médias de três repetições de cada tratamento, através dos procedimentos do Sistema SAS (1996).

\subsection{Resultados e Discussão}

\subsubsection{Oxidação do óleo de vísceras de aves}

Os resultados das análises de qualidade e de caracterização das amostras do óleo de vísceras fresco e oxidado estão apresentados nas Tabelas 2 e 3.

Como se pode observar na Tabela 2, os resultados obtidos para acidez e índice de peróxidos foram mais elevados para o óleo oxidado. Entretanto, a presença de compostos secundários decorrentes da oxidação (dienos e trienos), verificada através da absorbância específica, é o que efetivamente caracteriza o estado oxidativo do ingrediente.

Os resultados de absorbância específica das amostras de óleo oxidado apresentam valores bastante superiores aos das amostras iniciais, indicando formação de grande quantidade de compostos dienos e trienos em decorrência da oxidação. O óleo de vísceras fresco apresentou valores baixos (2,86 e 0,32 em 232 e $270 \mathrm{~nm}$, respectivamente) indicando pequena quantidade 
de compostos primários e secundários de ranço, enquanto que no óleo oxidado as absorbâncias específicas foram bem mais elevadas (10,53 e 1,97, em 232 e $270 \mathrm{~nm}$, respectivamente), o que revela um adiantado estado oxidativo.

Tabela 2. Resumo dos resultados analíticos do óleo de vísceras fresco e oxidado fornecido às aves $(n=1)$

\begin{tabular}{lccc}
\hline Análises & Unidades & Óleo Fresco & Óleo Oxidado \\
\hline Umidade $^{1}$ & $\%$ & 0,53 & 0,48 \\
Acidez $^{1}$ & $\mathrm{mg} \mathrm{KOH} / \mathrm{g}$ & 1,22 & 1,73 \\
Extrato etéreo $^{1}$ & $\%$ & 99,05 & 99,72 \\
Índice de peróxidos $^{1}$ & meq peróxidos/kg & 2,83 & 38,73 \\
Absorbância específica $^{2}$ & & & \\
\multicolumn{2}{c}{$232 \mathrm{~nm}$} & 2,86 & 10,53 \\
$270 \mathrm{~nm}$ & 0,32 & 1,97
\end{tabular}

${ }^{1}$ Análises realizadas no Laboratório CBOneida em Campinas, SP, em duplicata.

${ }^{2}$ Análises realizadas no Lab. Óleos e Gorduras da ESALQ/USP em Piracicaba/SP, em duplicata.

Além disso, pode-se verificar as alterações ocorridas também na composição dos ácidos graxos da amostra de óleo (Tabela 3). Quando as amostras do óleo fresco e do oxidado são comparadas, verifica-se que houve tendência de aumento nas concentrações dos ácidos graxos palmítico (C16:0), esteárico (C18:0) e oléico (C18:1) e de redução nos ácidos graxos palmitoléico (C16:1) e linolênico (C18:3), alterando substancialmente a proporção de saturados e insaturados em ambas amostras de óleo fresco e oxidado. Isso porque, o comprometimento das duplas ligações dos ácidos graxos insaturados devido à oxidação faz com que os compostos mais insaturadas deixem de ser identificados como tal na separação cromatográfica e haja um aumento na proporção dos compostos menos insaturados. 
Tabela 3. Perfil de ácidos graxos do óleo de vísceras de aves fresco e oxidado $(n=1)$

\begin{tabular}{lcc}
\hline Ácidos Graxos $(\%)^{1}$ & Óleo Fresco & Óleo Oxidado \\
\hline C14:0 mirístico & - & 0,58 \\
C16:0 palmítico & 24,91 & 30,37 \\
C16:1 palmitoléico & 9,55 & 9,39 \\
C18:0 esteárico & 5,84 & 6,16 \\
C18:1 oléico & 38,24 & 38,39 \\
C18:2 linoléico & 19,53 & 14,71 \\
C18:3 linolênico & 0,63 & 0,39 \\
C20:4 araquidônico & 1,29 & - \\
Total Saturados & 32,04 & 37,11 \\
Total Insaturados & 67,95 & 62,88 \\
\hline
\end{tabular}

${ }^{\mathrm{T}}$ Análises realizadas na Faculdade de Saúde Pública, USP, em São Paulo.

Verifica-se ainda uma acentuada diminuição da quantidade do ácido linoléico (C18:2), este que é justamente um dos ácidos graxos mais suscetíveis a oxidação e que foi degradado durante o processo, sendo que a sua oxidação gera grandes quantidades de compostos dienos encontrados na análise da absorbância específica.

\subsubsection{Desempenho das aves}

$\mathrm{Na}$ Tabela 4 estão resumidos os dados obtidos no ensaio de desempenho. Os valores médios de peso vivo e de consumo de ração dos animais que consumiram ração com o óleo oxidado foram ligeiramente inferiores em relação aos que consumiram ração com o óleo fresco, mas não apresentaram diferença estatística significativa. Os resultados médios de ganho de peso diário foram idênticos, e somente os valores médios de conversão alimentar foram estatisticamente diferentes $(P<0,05)$. A conversão 
alimentar foi melhorada $(1,759)$ pelo uso do óleo oxidado provavelmente devido ao menor consumo de ração deste tratamento.

Tabela 4. Resultados médios de peso vivo aos 42 dias, consumo de ração, conversão alimentar e ganho de peso diário individual para os animais experimentais no período de 10 a 42 dias de idade $(n=4)$

\begin{tabular}{lccc}
\hline Parâmetros & Óleo Fresco & Óleo Oxidado & CV (\%) \\
\hline Peso Vivo (kg) & 2,701 & 2,690 & 2,29 \\
Consumo de Ração $(\mathrm{kg})$ & 4,358 & 4,262 & 2,87 \\
Conversão Alimentar & $1,792^{\mathrm{a}}$ & $1,759^{\mathrm{b}}$ & 0,87 \\
Ganho Peso Diário $(\mathrm{kg})$ & 0,076 & 0,076 & 2,37 \\
a,b & Médias na mesma linha diferem estatisticamente entre si $(\mathrm{P}<0,05)$ pelo teste t.
\end{tabular}

Apesar do óleo oxidado apresentar características que comprovem o comprometimento da sua qualidade decorrente do seu avançado estado de oxidação, isto não foi suficiente para afetar o ganho de peso nem o consumo de ração dos animais com a adição de $4 \%$ de óleo às rações. Nem sempre tais efeitos sobre o desempenho de frangos de corte são detectados em experimentos semelhantes, assim como no trabalho de Kirkland e Fuller (1970), que não verificaram nenhuma influência do uso do mesmo tipo de óleo armazenado por 12 semanas sem nenhuma proteção antioxidante na alimentação de frangos de corte. Da mesma forma, Waldroup et al. (1981) não observaram diferenças significativas no peso vivo (oito semanas), ganho de peso ou na conversão alimentar de frangos de corte que consumiram rações com óleo de vísceras de aves fresco ou armazenado por três meses.

\subsubsection{Características da carcaça}

O fornecimento do óleo de vísceras de aves fresco ou oxidado na proporção de $4 \%$ na ração das aves também levou a resultados idênticos de peso vivo ao abate, com 47 dias (3,047 e 3,048 kg, respectivamente), assim 
como os pesos das carcaças evisceradas, sem pés, pescoço e cabeça $(2,163$ e 2,167 kg, respectivamente), parâmetros com baixos coeficientes de variação.

Tabela 5. Valores médios obtidos de peso vivo ao abate (47 dias), peso da carcaça eviscerada (sem pés, cabeça e pescoço), rendimento da carcaça, do peito e das pernas, rendimento da carne do peito e da carne da sobrecoxa e quantidade de gordura na carcaça para os tratamentos estudados $(n=60)$

\begin{tabular}{lccc}
\hline Parâmetros & Óleo Fresco & Óleo Oxidado & $\begin{array}{c}\text { C.V. } \\
(\%)\end{array}$ \\
\hline Peso Vivo (kg) & 3,047 & 3,048 & 5,17 \\
Peso Carcaça Eviscerada (kg) & 2,163 & 2,167 & 6,03 \\
Rendimento Carcaça (\%) & 70,95 & 71,11 & 2,59 \\
Rendimento Peito (\%) & 35,26 & 34,85 & 4,55 \\
Rendimento Carne Peito (\%) & 27,16 & 26,57 & 6,53 \\
Rendimento Perna (\%) & 32,23 & 31,76 & 3,98 \\
Rendimento Carne Sobrecoxa (\%) & $13,30^{\mathrm{a}}$ & $12,78^{\mathrm{b}}$ & 6,77 \\
Gordura abdominal (g) & 42,01 & 43,43 & 31,42 \\
Gordura abdominal (\%) & 1,94 & 2,00 & 30,65 \\
${ }^{\text {ab }}$ Médias na mesma linha diferem estatisticamente entre si (P<0,05) pelo teste t.
\end{tabular}

Os resultados do rendimento da carcaça e das partes (peito e perna) também não apresentaram diferenças estatísticas para os tratamentos estudados; entretanto, os valores médios de rendimento do peito $(35,26$ e 34,85 $\%$ para os tratamentos fresco e oxidado, respectivamente), da perna $(32,23$ e $31,76 \%$ para os tratamentos fresco e oxidado, respectivamente) e da carne do peito ( 27,16 e $26,57 \%$ para os tratamentos fresco e oxidado, respectivamente) foram numericamente superiores para o tratamento com o óleo fresco. Já os resultados de rendimento da carne da sobrecoxa foram superiores estatisticamente $(P<0,05)$ para o tratamento com óleo fresco. 
De uma maneira geral, segundo Albino et al. (2001), frangos de corte alimentados com níveis crescentes de energia nas rações apresentam melhora geral no desempenho (ganho de peso e conversão alimentar), maior deposição de gordura abdominal, mas nem sempre apresentam melhorias significativas no rendimento da carcaça ou das partes (peito e pernas). Benício $^{1}$, citado por Albino et al. (2001), verificou redução no rendimento de carne de coxa e sobrecoxa de aves alimentadas com maiores níveis de energia nas rações, provavelmente decorrente da maior deposição de gordura subcutânea em conseqüência do aumento do valor energético da ração fornecida.

Praticamente não há estudos que relacionem o uso de óleo oxidado nas dietas de frangos de corte e seus efeitos nas características da carcaça dos animais. Os efeitos negativos do óleo oxidado têm sido relacionados em parte com a presença de produtos tóxicos produzidos pelas reações de oxidação lipídica e em parte com seu menor valor biológico, destruição de vitaminas e carotenóides lipossolúveis, menor qualidade da proteína decorrente da reação da proteína da dieta com os produtos da oxidação, além de menores valores de energia (Lin et al., 1989a; Sheehy et al., 1994; Engberg et al., 1996).

Neste estudo, o nível energético da ração contendo óleo fresco provavelmente foi superior em relação ao da ração contendo óleo de oxidado, uma vez que a única diferença entre elas foi a qualidade do óleo oferecido. No entanto, tal diferença não foi evidenciada nas características de rendimento da carcaça ou das partes, uma vez que não houve diferenças estatisticamente significativas nas características de rendimento de uma forma geral para os animais que consumiram rações contendo óleo de vísceras fresco ou oxidado.

${ }^{1}$ BENÍCIO, L. A. S. Estudo da influência de linhagens e de níveis nutricionais sobre desempenho, rendimento de carcaça e avaliação econômica em frangos de corte. Viçosa: UFV, 1995, 159p. Tese (Doutorado em Zootecnia) - Universidade Federal de Viçosa, 1995. 


\subsubsection{Características da carne da sobrecoxa}

$\mathrm{Na}$ Tabela 6 podem-se observar os resultados da composição centesimal e do $\mathrm{pH}$ obtidos para as amostras da carne de sobrecoxa dos animais experimentais.

Os resultados encontrados para umidade, proteína bruta e matéria mineral são inferiores aos valores encontrados na literatura $(75,81 \%$ umidade, 19,65\% PB, 0,96\% matéria mineral, de acordo com a tabela do USDA National Nutrient Database for Standard Reference, Release 16-1, 2004) para carne de sobrecoxa de frango crua.

Já os resultados obtidos para gordura encontram-se superiores aos da literatura (7,3\% gordura de acordo com Mendes, 2001; 3,10\% gordura segundo Franco, 2001 e 3,91\% gordura total, de acordo com USDA National Nutrient Database for Standard Reference, Release 16-1, 2004).

Tabela 6. Teores de umidade, proteína bruta, gordura, matéria mineral e pH da carne de sobrecoxa $(n=3)$

\begin{tabular}{lcccc}
\hline Análises $^{1}$ & Unidades & Óleo Fresco & Óleo Oxidado & CV (\%) \\
\hline Umidade & $\%$ & 70,77 & 70,69 & 0,24 \\
Proteína Bruta & $\%$ & 17,97 & 17,83 & 1,10 \\
Gordura & $\%$ & 9,53 & 9,34 & 1,97 \\
Matéria mineral & $\%$ & 0,82 & 0,83 & 6,40 \\
$\mathrm{pH}^{2}$ & & 6,17 & 6,16 & 1,73
\end{tabular}

${ }^{1}$ Análises efetuadas em duplicata.

${ }^{2}$ Análise realizada $24 \mathrm{~h}$ após o abate, em duplicata.

Segundo Mendes (2001), a composição química dos músculos das aves é diretamente afetada pela genética, nutrição, idade da ave e pelo ambiente, portanto, a ocorrência destas variações de composição pode ser considerada normal, uma vez que os frangos foram abatidos com peso médio 
superior a 3,0 $\mathrm{kg}$ aos 47 dias de idade e dadas as possíveis diferenças entre os músculos analisados.

Os resultados obtidos para o pH 24 horas após o abate foram 6,17 e 6,16 para os tratamentos com óleo fresco e oxidado, respectivamente, e estão próximos dos valores encontrados na literatura para carne de coxa e sobrecoxa (entre 6,20 e 6,70, de acordo com Mendes, 2001). Durante os 12 dias de armazenamento $\mathrm{o} \mathrm{pH}$ foi monitorado e manteve-se em torno de 6,02 e 6,03 (valores médios) para os tratamentos fresco e oxidado, respectivamente.

De uma maneira geral, os tratamentos aplicados não afetaram a composição das amostras de carne, exceto uma pequena variação na porcentagem de gordura do músculo.

Os resultados do perfil de ácidos graxos, lipídios totais e colesterol total obtidos para as amostras de carne de sobrecoxa estão apresentados na Tabela 7. Assim como já observado em estudos anteriores (Asghar et al., 1989; Lin et al., 1989a), os ácidos graxos C16 (palmítico e palmitoléico) e C18 (esteárico, oléico e linoléico) são os que prevalecem e representam mais de 80\% do total de ácidos graxos da fração lipídica da carne.

As quantidades de ácidos graxos saturados e insaturados nas amostras de sobrecoxa estão de acordo com os valores apresentados por Rhee et al. (1996), de 30,60\% de saturados e $64,57 \%$ de insaturados. Contudo, o tratamento com óleo oxidado resultou em carnes contendo níveis ligeiramente mais altos de saturados e mais baixos de insaturados em relação ao tratamento com óleo fresco.

Praticamente não foram verificadas diferenças entre as concentrações da maioria dos ácidos graxos, assim como Sheehy et al. (1994). As alterações verificadas em alguns ácidos graxos são pequenas e decorrem das modificações encontradas no óleo de vísceras utilizado na dieta. As concentrações dos ácidos graxos palmitoléico e esteárico foram maiores para o tratamento com óleo oxidado, já o valor do ácido linoléico foi mais baixo, o que pode ser explicado pela menor concentração deste ácido graxo encontrado no 
óleo oxidado fornecido aos animais devido a sua destruição decorrente do processo de oxidação a que o óleo foi submetido.

Tabela 7. Perfil dos ácidos graxos (\%) da fração lipídica e colesterol total (mg/100 g de amostra) da carne de sobrecoxa $(n=4)$

\begin{tabular}{lccc}
\hline Análises $^{1}$ & Óleo Fresco & Óleo Oxidado & CV (\%) \\
\hline C16:0 palmítico & 23,42 & 23,28 & 2,5 \\
C16:1 palmitoléico & 3,84 & 4,74 & 7,8 \\
C18:0 esteárico & 10,05 & 11,05 & 1,9 \\
C18:1 oléico & 30,75 & 29,70 & 3,4 \\
C18:2 linoléico & 20,60 & 19,80 & 3,0 \\
Total Saturados & 33,52 & 34,32 & 4,7 \\
Total Insaturados & 66,53 & 64,94 & 2,7 \\
Colesterol Total & 52,26 & 77,73 & 21,66
\end{tabular}

${ }^{1}$ Análises realizadas na Faculdade de Saúde Pública, USP em São Paulo, em quatro amostras/ tratamento.

O conteúdo de colesterol apresentou grande diferença entre os tratamentos, sendo maior para o óleo oxidado $(77,73 \mathrm{mg} / 100 \mathrm{~g})$ que para o óleo fresco (52,26 mg/100g). Estes resultados discordam dos de Grau et al. (2001), que não verificaram alterações nos valores de colesterol total fornecendo óleo de girassol fresco ou oxidado a frangos de corte. Segundo os autores, estes resultados ocorreram em função do baixo grau de comprometimento do óleo oxidado.

\subsubsection{Ensaio de armazenamento refrigerado}

\subsubsection{Valores de TBARS}

As alterações oxidativas na carne de sobrecoxa armazenada sob refrigeração durante 12 dias podem ser observadas na Tabela 8. Os resultados de TBARS variaram de 0,379 até 0,580 $\mathrm{mg}$ de malonaldeído/kg de amostra 
para o tratamento fresco e de 0,560 até $0,720 \mathrm{mg}$ de malonaldeído/kg de amostra para o tratamento oxidado.

Tabela 8. Valores médios de TBARS (mg malonaldeído/kg de amostra) na carne de sobrecoxa armazenada por 12 dias sob refrigeração $(n=3)$

\begin{tabular}{lcccccc}
\hline \multirow{2}{*}{ Tratamento } & \multicolumn{6}{c}{ TBARS } \\
& 1 dia & 4 dias & 8 dias & 12 dias & Média & C.V.(\%) \\
\hline Fresco & 0,379 & 0,535 & 0,473 & 0,580 & $0,492^{\mathrm{b}}$ & 20,95 \\
Oxidado & 0,560 & 0,701 & 0,720 & 0,633 & $0,654^{\mathrm{a}}$ & 17,90 \\
\hline \multicolumn{2}{l}{${ }^{\mathrm{ab}}$ Médias na mesma coluna diferem estatisticamente $(\mathrm{P}=0,0016)$ pelo teste t. }
\end{tabular}

Ao final dos 12 dias de armazenamento, nota-se que os valores de TBARS foram significativamente superiores $(P=0,0016)$ para as amostras de carne do tratamento com óleo oxidado em relação ao óleo fresco. Estes resultados comprovam a maior susceptibilidade à oxidação da carne de aves alimentadas com rações contendo óleo oxidado, assim como estudos anteriores (Asghar et al., 1989; Lin et al., 1989b; Sheehy et al., 1994; Galvin et al., 1997; Jensen et al., 1997).

Existe uma relação bem estabelecida entre os valores médios de TBARS e as avaliações sensoriais de carne (Bou et al., 2001). De acordo com Olivo \& Shimokomaki (2002), produtos cárneos com índice de TBARS menores que $1,0 \mathrm{mg} / \mathrm{kg}$, geralmente não apresentam sabores e odores residuais de ranço característicos de oxidação lipídica. Já Galvin et al. (1997) afirmam que "off-flavours" podem ser detectados em carnes oxidadas a partir de valores de TBARS entre 0,500 e $2,00 \mathrm{mg} / \mathrm{kg}$ de carne. Os resultados de TBARS deste estudo indicam que a inclusão de óleo oxidado na dieta dos animais provocou diminuição da estabilidade da carne de sobrecoxa, mas provavelmente não foi suficiente para resultar em alterações sensoriais indesejáveis perceptíveis na carne armazenada. 
Houve ainda uma redução dos valores de TBARS do tratamento oxidado no último dia de armazenamento, no entanto, tal fato já foi anteriormente observado em ensaios com carne oxidada congelada (Galvin et al., 1997). Segundo os autores, esta variação nos valores de TBARS pode ser resultado de reações dos malonaldeídos com proteínas ou pode estar relacionada com interferência de reações de polimerização.

\subsubsection{Cor}

A cor é um importante atributo de qualidade de comercialização que influencia na aceitação dos consumidores aos diversos produtos alimentícios, inclusive na carne de frango. Segundo Jensen et al. (1998), a taxa de descoloração das carnes frescas está diretamente relacionada com a taxa de oxidação dos pigmentos e com a eficiência dos sistemas enzimáticos redutores da metamioglobina. O completo funcionamento dos mecanismos de manutenção da estabilidade da pigmentação das carnes ainda não é completamente conhecido. Olivo \& Shimokomaki (2002) sustentam a existência de uma interdependência entre a oxidação lipídica e a formação de metamioglobina, uma vez que a oxidação dos pigmentos pode catalisar a oxidação lipídica e os radicais livres produzidos durante a oxidação lipídica podem oxidar o pigmento heme.

Recentemente, muitos estudos têm sido realizados com a finalidade de avaliar o fenômeno PSE (pale, soft and exudative) na carne de frango. De acordo com Van Laack et al. (2001), peitos com baixa capacidade de retenção de água (CRA) podem ser chamados PSE, mas este fenômeno em frangos difere em suínos ou perus pois a desnaturação protéica parece não ser a principal causa da palidez e da baixa CRA. Acredita-se que para carne de frango, o baixo $\mathrm{pH}$ seja o principal fator determinante. Carnes de frango com baixo $\mathrm{pH}$ têm sido associadas com baixa CRA, o que resulta em maiores perdas por gotejamento e por cozimento, resultando em menor maciez (Allen et al., 1998). 
Para Boulianne e King (1995), parece existir relação entre cor da carne fresca crua e o seu $\mathrm{pH}$, ambos associados às propriedades funcionais da carne. Segundo Quiao et al. (2001), o valor L* (luminosidade) dentre as demais medidas de cor $\left(L^{*}, a^{*}\right.$ e $\left.b^{\star}\right)$, é o que tem a mais alta correlação com o PSE. Peitos com $L^{*}$ maior que 49 (muito claros) apresentam baixa CRA e são classificados como carne PSE.

Tabela 9. Valores médios de $L^{*}, a^{*}$ e $b^{*}$ para as amostras de carne de sobrecoxa armazenadas sob refrigeração $(n=3)$

\begin{tabular}{ccccccc}
\hline Dias de & \multicolumn{3}{c}{ Óleo Fresco } & \multicolumn{3}{c}{ Óleo Oxidado } \\
armazenamento & $\mathrm{L}^{*}$ & $\mathrm{a}^{*}$ & $\mathrm{~b}^{*}$ & $\mathrm{~L}^{*}$ & $\mathrm{a}^{*}$ & $\mathrm{~b}^{*}$ \\
\hline 1 & 55,40 & 4,02 & 4,91 & 56,70 & 5,49 & 4,87 \\
4 & 53,60 & 5,03 & 8,70 & 55,30 & 4,12 & 5,92 \\
8 & 53,90 & 2,98 & 6,62 & 54,50 & 3,63 & 7,00 \\
12 & 53,30 & 5,85 & 5,22 & 53,80 & 4,70 & 5,75 \\
Médias & 54,05 & 4,47 & 6,36 & 55,08 & 4,49 & 5,89 \\
CV (\%) & 3,38 & 40,84 & 30,03 & 4,63 & 33,69 & 21,09 \\
\hline
\end{tabular}

Neste estudo (Tabela 9), apesar das amostras de sobrecoxa dos dois tratamentos apresentaram valores altos de $L^{*}$ (luminosidade), ambos acima de 49, estas não se classificam como carne PSE, uma vez que o pH encontra-se dentro da normalidade. Tal fato pode ser devido à posição de leitura da cor no músculo (parte dorsal), além disso, provavelmente o contato prolongado da carne da sobrecoxa durante todo o abate e transporte com gelo e água gelada pode ter causado perda dos pigmentos e queima da superfície do músculo, elevando os valores de $L^{\star}$ das amostras. Este efeito do contato da carne com gelo e água gelada sobre as leituras de cor também foi descrito por Boulianne e King (1995), quando avaliaram parâmetros de cor em peitos de frango desossados e sem pele. 
O objetivo da determinação de cor neste estudo foi avaliar se o prejuízo na estabilidade oxidativa da carne associada ao consumo de óleo oxidado na dieta estava relacionado com alterações na cor do produto. Os tratamentos aplicados não tiveram influência sobre os parâmetros de cor na carne da sobrecoxa refrigerada, uma vez que as diferenças não foram estatisticamente significativas. Contudo, nota-se que os valores obtidos para o $L^{*}$ foram mais altos, em todos os intervalos de armazenamento, para 0 tratamento com óleo oxidado em relação ao tratamento com óleo fresco.

\subsection{Conclusões}

O consumo de ração contendo $4 \%$ de óleo de vísceras oxidado por frangos de corte de 10 a 47 dias de idade não causou prejuízos no desempenho das aves ou nas características da carcaça.

A estabilidade oxidativa da carne da sobrecoxa armazenada sob refrigeração, medida pelo TBARS, foi prejudicada devido ao consumo de óleo oxidado na dieta. 


\section{EFEITOS DO ÓLEO DE VÍSCERAS DE AVES OXIDADO NA RAÇÃO NO DESEMPENHO DE FRANGOS DE CORTE E NA ESTABILIDADE OXIDATIVA DA CARNE DE SOBRECOXA ARMAZENADA SOB CONGELAMENTO}

\section{Resumo}

Foi conduzido um ensaio utilizando-se 200 pintos de corte da linhagem AgRoss de 10 a 40 dias de idade alimentados com ração à base de milho e farelo de soja e suplementados com $4 \%$ de óleo de vísceras de aves fresco ou oxidado com a finalidade de avaliar os efeitos da qualidade do óleo utilizado nas rações sobre o desempenho de frangos de corte e sobre a estabilidade oxidativa da carne de sobrecoxa congelada. Um lote de óleo de vísceras recém produzido foi armazenado congelado $\left(-18{ }^{\circ} \mathrm{C}\right)$ para que suas características originais fossem mantidas até o momento da produção das rações. O óleo oxidado foi produzido a partir deste mesmo lote aquecendo-o em uma fritadeira elétrica com temperatura em torno de 110 a $120^{\circ} \mathrm{C}$ por 20 dias. As quantidades de compostos de ranço contidas no óleo mantido congelado e no óleo oxidado foram avaliadas através da análise das absorbâncias específicas a 232 e $270 \mathrm{~nm}$ (5,80 e 0,69 para o óleo fresco e 11,33 e 2,31 para o oxidado, respectivamente). Aos 41 dias de idade, 168 animais foram abatidos para avaliação das características de rendimento da carcaça e das partes, as sobrecoxas desossadas e sem pele foram embaladas e mantidas na câmara de 
congelamento do abatedouro. A determinação de TBARS (Thiobarbituric acid reactive substances) foi empregada para avaliar mensalmente o estado oxidativo da carne de sobrecoxa congelada. O uso do óleo de vísceras oxidado não afetou o desempenho das aves, nem as características principais da carcaça. A partir do sexto mês de armazenamento, a estabilidade oxidativa da carne de sobrecoxa congelada foi comprometida $(P<0,10)$ pelo consumo de rações contendo $4 \%$ de óleo oxidado, mas a cor não foi afetada.

\section{Summary}

The effects of dietary oxidized poultry offal fat on broiler perfomance and oxidative stability of frozen thigh meat

In order to evaluate the effects of dietary oil quality on broiler performance and on oxidative stability of frozen thigh meat during nine months of storage, 200 male AgRoss broiler chicks were raised from 10 to 40 days of age and fed a corn-soy diet with $4 \%$ of fresh or oxidized poultry fat. Fresh poultry fat whose specific absorbances were 5.80 and 0.69 at 232 and $270 \mathrm{~nm}$, respectively, was supplied by a local rendering and stored frozen $\left(-18^{\circ} \mathrm{C}\right)$ until diets were produced. Oxidized poultry fat was obtained by heating in a fryer at $110-120{ }^{\circ} \mathrm{C}$ during 20 days when specific absorbances reached 11.33 and 2.31 at 232 and $270 \mathrm{~nm}$, respectively. One hundred and sixty-eight birds were slaughtered at 41 days of age and carcass characteristics were assessed. Skinless and deboned raw thigh meat was packed and stored in a nonilluminated freezer at $-20^{\circ} \mathrm{C}$. TBARS (Thiobarbituric acid reactive substances) were determined monthly in the frozen samples to evaluate the oxidative status of meat stored. Birds performance and carcass characteristics were not affected by the presence of oxidized poultry fat in the diets. Oxidative stability of frozen thigh muscle from broilers fed oxidized poultry fat in the diet was reduced from 
the sixth month of storage since TBARS values were statistically higher $(P<0.10)$.

\subsection{Introdução}

$\mathrm{Na}$ avicultura moderna, óleos e gorduras são incorporados às dietas objetivando principalmente fornecer grande quantidade de energia, fornecer ácidos graxos essenciais, melhorar a conversão alimentar, reduzir o incremento calórico, facilitar a absorção das vitaminas lipossolúveis, melhorar a palatabilidade das rações, além de apresentar outras vantagens operacionais na fábrica de rações.

O óleo de vísceras de aves é uma importante fonte de energia nos dias atuais, mas, por outro lado, apresenta alta concentração de ácidos graxos insaturados em sua composição (NRC, 1994), que são facilmente oxidados. Este processo compromete a sua qualidade, palatabilidade e a eficiência de aproveitamento de vários nutrientes pelos animais (Lin et al., 1989b; Engberg et al., 1996).

O consumo de alimento oxidado por frangos de corte pode levar a prejuízos no desempenho das aves (Asghar et al., 1989; Lin et al., 1989b; Sheehy et al., 1994; Engberg et al., 1996) em função do seu menor valor biológico e da presença de grandes quantidades de compostos de ranço que são considerados tóxicos e podem prejudicar a absorção de outros nutrientes, como as vitaminas lipossolúveis e certos ácidos graxos essenciais (Cabel et al., 1988). Além disso, a estabilidade oxidativa dos tecidos musculares é seriamente comprometida pelo consumo de alimentos oxidados (Asghar et al., 1989; Lin et al., 1989b), uma vez que a presença de radicais livres resultantes da ingestão de alimento oxidado reduz a concentração de $\alpha$-tocoferol presente nos tecidos (Jensen et al., 1997; Jensen et al., 1998; Grau et al., 2001b).

Como a oxidação lipídica é considerada o principal fator de perda de qualidade e das propriedades funcionais da carne e seus produtos (Jensen 
et al., 1998), o objetivo deste estudo foi avaliar como a inclusão de óleo de vísceras de aves oxidado na dieta influencia a estabilidade lipídica da carne de sobrecoxa de frangos de corte durante seu armazenamento congelado. Ainda foram estudadas as influências dessa dieta sobre o desempenho dos animais e as características da carcaça e da carne produzida.

\subsection{Material e Métodos}

\subsection{1 Óleo de vísceras de aves}

Um lote de óleo de vísceras de aves, imediatamente após sua extração sem o uso de antioxidante, foi recebido de um fornecedor regional, sendo retirada uma amostra para avaliação da qualidade e da composição inicial do produto. Uma parte deste óleo (cerca de $30 \mathrm{~kg}$ ), foi imediatamente acondicionada em embalagens plásticas e armazenada em congelador apropriado à temperatura de $-18^{\circ} \mathrm{C}$, para que as suas características originais fossem mantidas até o momento da produção das rações experimentais. Este foi considerado o óleo de vísceras fresco.

O processo de oxidação do óleo de aves restante (cerca de $50 \mathrm{~kg}$ ) foi conduzido no Laboratório de Óleos e Gorduras do Departamento de Agroindústria, Alimentos e Nutrição, da ESALQ/USP, através do aquecimento em uma fritadeira elétrica Tedesco, modelo FAO-30. O equipamento era ligado pela manhã $(7: 30 \mathrm{~h})$ e desligado à tarde $(18: 00 \mathrm{~h})$, ficando o óleo sob temperaturas entre 110 e $120{ }^{\circ} \mathrm{C}$ durante todo o dia por 20 dias consecutivos.

Durante o período de oxidação do óleo foram retiradas amostras periódicas para quantificação de produtos da oxidação (dienos e trienos) presentes no óleo, visando acompanhar o estado oxidativo do ingrediente. $O$ método utilizado foi o IUPAC número II.D.23 (1979), que determina a absorbância do óleo no espectro ultravioleta e fornece uma indicação do seu grau de deterioração decorrente da oxidação lipídica. Tais análises foram 
realizadas no Laboratório de Óleos e Gorduras do Departamento de Agroindústria e Nutrição da ESALQ/USP.

\subsubsection{Ensaio de desempenho}

Para o ensaio de desempenho foram utilizados 200 pintos de um dia, machos, da linhagem AgRoss, e alojados num galpão experimental do Departamento de Zootecnia da ESALQ/USP. Os animais foram divididos em dois tratamentos com quatro boxes cada, sendo 25 aves por box (unidade experimental).

Durante os primeiros dias de vida as aves foram alojadas em círculo de proteção com aquecimento feito através de campânula a gás. Somente após os 10 dias de idade as aves foram transferidas para os boxes, quando passaram a receber os tratamentos experimentais: dieta contendo $4 \%$ de óleo de vísceras de aves fresco ou oxidado.

A ração foi formulada para atender às exigências das aves dos 10 dias até o abate (fase única, Tabela 1) de acordo com Rostagno (2000). As aves receberam ração e água à vontade e luz natural.

Semanalmente foram feitas pesagens das aves e da ração para determinação do peso vivo, ganho de peso e consumo de ração no período. O ensaio de desempenho foi encerrado aos 40 dias de idade das aves, quando foi efetuada a última pesagem dos animais e da ração. Além disso, os animais também foram pesados individualmente e cada ave foi identificada com uma anilha numerada em uma das patas. 
Tabela 1. Composição percentual da ração experimental e níveis calculados dos nutrientes

\begin{tabular}{lc}
\hline Ingredientes & $\%$ \\
\hline Milho & 60,00 \\
Farelo de Soja 45,5\% PB & 32,00 \\
Óleo de vísceras de aves ${ }^{1}$ & 4,00 \\
Fosfato Bicálcico & 1,70 \\
Calcário Calcítico & 1,00 \\
Sal & 0,500 \\
Suplemento Vitamínico ${ }^{2}$ & 0,300 \\
Suplemento Mineral & \\
DL-Metionina & 0,050 \\
L-Lisina.HCl & 0,250 \\
& 0,260 \\
EMA kcal/kg & \\
PB \% & 3.153 \\
Extrato Etéreo \% calculados & 20,00 \\
Metionina \% & 6,50 \\
Met + Cis \% & 0,553 \\
Lisina \% & 0,870 \\
Cálcio \% & 1,240 \\
Fósforo disponível \% & 0,950 \\
\hline
\end{tabular}

\footnotetext{
${ }^{1}$ Tratamentos: substituição pelo óleo fresco ou oxidado.

${ }^{2}$ Concentração por kg de ração: ácido fólico, 0,999 mg; ácido pantotênico, $15 \mathrm{mg}$; BHT, 22,5 mg; biotina, 0,06 mg; colina, 339 mg; niacina, 40 mg; selênio, 0,3 mg; vit. A, 7.998,00 Ul; vit. $D_{3}$, $1,998 \mathrm{UI}$; vit. E, $15 \mathrm{Ul}$; vit. K, 1,8 mg; tiamina, 1,8 mg; riboflavina, 6,0 mg; piridoxina, 2,8 mg; vit. $\mathrm{B}_{12} 12 \mathrm{mcg}$; olaquindox $40 \mathrm{mg}$; avilamicina $5 \mathrm{mg}$; nicarbazina $110 \mathrm{mg}$.

${ }^{3}$ Concentração por kg de ração: manganês, 75 mg; zinco, 50 mg; ferro, 50 mg; cobre, 8 mg; iodo, $0,75 \mathrm{mg}$.
} 


\subsubsection{Abate e ensaio de armazenamento congelado}

Aos 41 dias de idade, 136 aves (68 de cada tratamento) foram abatidas no abatedouro experimental da Faculdade de Medicina Veterinária e Zootecnia da UNESP, em Botucatu/SP. As aves foram transportadas em engradados de plástico (oito aves por caixa) durante a madrugada. Os animais foram pesados individualmente na plataforma de recebimento, logo depois foram atordoados, abatidos, escaldados e depenados. Em seguida, foi feita a evisceração, sendo separada a porção de gordura abdominal. A carcaça eviscerada, sem cabeça, pés e pescoço, foi pesada para o cálculo do seu rendimento.

Na seqüência, foi feita a separação de partes (peito e pernas), e foram pesados o peito e as pernas inteiras, além da gordura abdominal. Em seguida, foram desossados peito e sobrecoxa. O peso da carne do peito e da sobrecoxa permitiu o cálculo do rendimento em carne destas partes. A carne da sobrecoxa (duas partes) foi acondicionada em sacos plásticos e encaminhada diretamente para a câmara de congelamento do abatedouro até estar completa e uniformemente congelada. Somente as amostras destinadas aos parâmetros iniciais (tempo zero) foram mantidas em caixa de isopor com gelo durante o transporte até a ESALQ, em Piracicaba, onde foram mantidas resfriadas e analisadas em seguida.

As amostras de carne de sobrecoxa congeladas e embaladas foram transportadas posteriormente em caixa de isopor com gelo da câmara de congelamento do abatedouro, em Botucatu, para o Laboratório de Óleos e Gorduras na ESALQ, em Piracicaba. As amostras foram armazenadas em congelador com temperatura média de $-18{ }^{\circ} \mathrm{C}$ durante os nove meses seguintes, sendo, a cada mês, retirada aleatoriamente três amostras de cada tratamento para análise. 


\subsubsection{Análises químicas da carne de frango}

As análises químicas da carne de sobrecoxa foram realizadas no Laboratório de Óleos e Gorduras do Departamento de Agroindústria, Alimentos e Nutrição da ESALQ/USP. As análises executadas foram: gordura, proteína bruta, umidade, matéria mineral, carboidratos totais (por diferença), pH, TBARS, extração e metilação dos lipídios da carne. O perfil dos ácidos graxos das amostras de óleo de vísceras e de carne foi obtido através de injeção em cromatógrafo gasoso (CG) no Laboratório de Pesticidas do Departamento de Entomologia da ESALQ/USP, após a devida extração e metilação. As determinações de cor através das leituras de $L^{*}, a^{*} e b^{*}$ foram executadas no Laboratório de Irradiação de Alimentos, no Centro de Energia Nuclear na Agricultura (CENA), em Piracicaba/SP.

\subsubsection{Composição centesimal}

A carne da sobrecoxa foi caracterizada através da sua composição em gordura e proteína bruta, de acordo com a AOCS (1990), pelo teor de umidade e de matéria mineral, segundo a AOAC (1995) e os carboidratos totais foram calculados pela diferença. Estas análises foram executadas em duplicata em três amostras de cada tratamento, somente nas amostras iniciais, no primeiro dia do experimento.

\subsubsection{2 $\mathrm{pH}$}

$\mathrm{O} \mathrm{pH}$ foi determinado com o uso de um potenciômetro em uma mistura de partes iguais, de amostra e de água bidestilada, após homogeneização em um processador de alimentos. As determinações foram realizadas em duplicata em três amostras de cada tratamento 24 horas após o abate e mensalmente juntamente com as determinações de TBARS. 


\subsubsection{Cor}

A cor foi determinada na parte ventral do músculo, através de quatro leituras em três amostras inteiras de sobrecoxa para cada tratamento estudado, utilizando-se o colorímetro Chroma meter - 200b da marca MINOLTA, pelo sistema $L^{*}$ (luminosidade), $a^{*}$ croma variando do vermelho $(+)$ ao verde $(-)$ e $b^{*}$ croma variando do amarelo (+) ao azul (-). As determinações foram efetuadas mensalmente durante os nove meses de armazenamento.

\subsubsection{TBARS (Thiobarbituric acid reactive substances)}

As determinações de TBARS foram feitas mensalmente em duplicata em três amostras de cada tratamento, segundo a metodologia de Tarladgis et al. (1960). Os produtos primários da oxidação lipídica constituemse principalmente de hidroperóxidos, que são rapidamente decompostos em várias substâncias reativas ao ácido 2-tiobarbitúrico (TBA), sendo o malonaldeído o elemento mais importante. O produto da reação destes compostos secundários com o TBA é colorido e absorve fortemente a $532 \mathrm{~nm}$.

O padrão utilizado nesta reação é o 1,1',3,3" tetraetoxipropano (TEP), cuja hidrólise ácida gera malonaldeído na proporção de 1:1 mol. Desta forma, é possível expressar os resultados em "valor de TBARS" (thiobarbituric acid reactive substances), expresso em $\mathrm{mg}$ de malonaldeído/1000g de amostra.

Para execução da análise, as amostras das sobrecoxas foram picadas e $100 \mathrm{~g}$ foram pesadas e homogeneizadas em um processador de alimentos com $10 \mathrm{~mL}$ de solução de BHT na concentração de $1 \mathrm{mg} / \mathrm{mL}$ de etanol, para que a amostra não sofresse oxidação durante o preparo. Foram pesados $10 \mathrm{~g}$ de cada amostra (em duplicata) em balões volumétricos de 250 $\mathrm{mL}$. Em seguida foram adicionados de $96,5 \mathrm{~mL}$ de água destilada, 2,5 $\mathrm{mL}$ de solução de ácido clorídrico $4 \mathrm{~N}, 1 \mathrm{~mL}$ da solução de BHT em etanol, algumas gotas de antiespumante e contas de vidro e dado início à destilação.

O líquido destilado, cerca de $50 \mathrm{~mL}$, foi recolhido em um copo de vidro (bequer). Três mililitros deste destilado foram pipetados e transferidos 
para um tubo de ensaio com tampa, no qual foram adicionados outros $3 \mathrm{~mL}$ de TBA 0,02 M. Em seguida, as amostras foram colocadas em banho-maria a 100 ${ }^{\circ} \mathrm{C}$ por 20 minutos, seguido pela leitura em espectrofotômetro a $532 \mathrm{~nm}$.

Para a elaboração da curva padrão, as amostras de sobrecoxa de frango alimentados com óleo fresco foram preparadas da mesma forma citada anteriormente, sendo utilizadas diferentes quantidades $(0,0 ; 0,5 ; 1,0 ; 2,0 ; 5,0$; 8,0 e 10,0 mL) de 1,1', 3,3" tetraetoxipropano (TEP), $2,5 \mathrm{~mL}$ de ácido clorídrico $4 \mathrm{~N}, 1,0 \mathrm{~mL}$ de BHT e 96,5, 96,0, 95,5, 94,5, 91,5, 88,5, 86,5 mL de água destilada, respectivamente, conforme as quantidades de TEP utilizadas. Foram preparados também balões sem amostras com as mesmas concentrações de TEP, ácido clorídrico e BHT, e 106,5, 106,0, 105,5, 104,5, 101,5, 98,5 e 96,5 $\mathrm{mL}$ de água destilada.

O teor de malonaldeído na amostra $(\mu \mathrm{g}$ de malonaldeído $/ \mathrm{mL}$ do destilado) foi calculado utilizando-se a equação da curva padrão sem amostra e, em seguida, utilizou-se a seguinte fórmula para obtenção do resultado em $\mathrm{mg}$ malonaldeído/1000 g de amostra:

$\mathrm{mg}$ de malonaldeído $/ 1000 \mathrm{~g}=\mu \mathrm{g}$ de malonaldeído $/ \mathrm{mL} \times 50 \times 1000 \times 100$

$A \times B \times 1000$

Em que:
A: peso da amostra
B: \% de recuperação do padrão

\subsubsection{Perfil de ácidos graxos}

Para a extração dos lipídios da carne de sobrecoxa usou-se a metodologia de Bligh \& Dyer (1959), segundo algumas modificações propostas por Christie (1982) e Smedes \& Thomasen (1996). Foram pesados $10 \mathrm{~g}$ de amostra úmida triturada (com cerca de 65 a $70 \%$ de umidade) e o tecido foi homogeneizado durante 4 minutos com uma mistura de $10 \mathrm{~mL}$ de clorofórmio e $20 \mathrm{~mL}$ de metanol em mesa agitadora. Em seguida, foram adicionados mais 10 
$\mathrm{mL}$ de clorofórmio e procedeu-se a agitação por mais um minuto. A mistura foi filtrada e o resíduo do papel de filtro foi lavado com mais $10 \mathrm{~mL}$ de clorofórmio para um melhor rendimento da extração. O filtrado foi transferido para um funil de separação de $250 \mathrm{~mL}$, adicionado de $10 \mathrm{~mL}$ de solução de $\mathrm{KCl}$ 0,88\% e agitado vigorosamente. Formou-se um sistema bifásico e a fase inferior contendo os lipídios purificados diluídos em clorofórmio foi filtrada em papel de filtro contendo sulfato de sódio anidro e coletada em balão volumétrico previamente pesado. $O$ solvente foi totalmente evaporado utilizando-se gás nitrogênio e, em seguida, as amostras foram pesadas para a determinação da quantidade de óleo obtido.

As amostras de óleo de vísceras (fresco e oxidado), bem como do óleo extraído da carne de sobrecoxa foram esterificadas e metiladas de acordo com metodologia de Hartman \& Lago (1973). Foram pesados 100-200 mg de óleo em fracos de $50 \mathrm{~mL}$ providos de condensador para saponificação com 5 $\mathrm{mL}$ de solução metanólica $0,5 \mathrm{~N}$ de $\mathrm{KOH}$ sob fervura. Adicionaram-se $15 \mathrm{~mL}$ do reagente de esterificação à solução quente e a mistura foi aquecida sob refluxo por 3 minutos. Em seguida, transferiu-se a amostra para um funil de separação usando $25 \mathrm{~mL}$ de éter e $50 \mathrm{~mL}$ de água. A fase inferior, aquosa, foi descartada e a fase etérea foi lavada duas vezes com $25 \mathrm{~mL}$ de água e o solvente evaporado parcialmente em fluxo de nitrogênio. As amostras foram então transferidas para frascos escuros e tampados e guardadas $a-18{ }^{\circ} \mathrm{C}$ até $\mathrm{o}$ momento da injeção.

Para determinação do perfil dos ácidos graxos nas amostras metiladas foi usado um cromatógrafo gasoso (ThermoQuest Trace CG) com detector FID (flame-ionization detector) e coluna capilar de sílica de $100 \mathrm{~m} \mathrm{x}$ $0,25 \mathrm{~mm} \times 0,2 \mu\left(S P^{\mathrm{TM}}-2560\right)$. As condições de injeção foram: temperatura do forno a $175^{\circ} \mathrm{C}$ por $27 \mathrm{~min}$ (taxa de $13^{\circ} \mathrm{C} / \mathrm{min}$ ), de 175 a $215^{\circ} \mathrm{C}$ por $11 \mathrm{~min}(4$ ${ }^{\circ} \mathrm{C} / \mathrm{min}$ ) e de 215 a $240{ }^{\circ} \mathrm{C}$ por $4 \mathrm{~min}\left(4^{\circ} \mathrm{C} / \mathrm{min}\right)$; temperatura de injeção (split com fluxo de $90 \mathrm{~mL} / \mathrm{min}$ ) $250^{\circ} \mathrm{C}$; temperatura do FID $300^{\circ} \mathrm{C}$; volume de injeção $1 \mu \mathrm{L}$; gás hidrogênio de arraste com fluxo de $1,8 \mathrm{~mL} / \mathrm{min}$. Foram analisadas três 
repetições por tratamento para as amostras de carne de sobrecoxa e uma amostra de cada tipo de óleo de vísceras. Os resultados foram expressos em \% do conteúdo total dos ácidos graxos.

\subsubsection{Análise estatística}

Para avaliar os efeitos dos dois tratamentos estudados (óleo fresco ou oxidado) em relação aos parâmetros observados foi utilizado o teste t para comparação das médias de três repetições de cada tratamento, através dos procedimentos do Sistema SAS (1996).

\subsection{Resultados e Discussão}

\subsubsection{Oxidação do óleo de vísceras de aves}

Os resultados das análises executadas nas amostras de óleo de vísceras de aves fresco ou oxidado antes da sua utilização na produção das rações experimentais estão apresentados nas Tabelas 2 e 3.

Através da observação da Tabela 2 pode-se notar que a composição inicial do óleo de vísceras era normal para umidade e teor de extrato etéreo, no entanto, apesar de recém extraído, o óleo já apresentava um alto índice de acidez, o que indica a presença de grandes quantidades de ácidos graxos livres naquele produto. Apesar do processo de extração do óleo ter sido acompanhada, a qualidade da matéria-prima utilizada não era conhecida. Portanto, é provável que essa matéria-prima tenha sido armazenada por um tempo excessivo antes da extração do óleo, permitindo o início do processo de lipólise, com conseqüente quebra dos triglicerídios e liberação dos ácidos graxos decorrente da ação da umidade, de enzimas ou da presença de microrganismos. 
Tabela 2. Caracterização dos óleos de vísceras fresco e oxidado utilizados na produção das rações experimentais $(n=1)$

\begin{tabular}{lccc}
\hline Análises & Unidades & Óleo Fresco & Óleo Oxidado \\
\hline Umidade $^{1}$ & $\%$ & 2,47 & 0,40 \\
Acidez $^{1}$ & $\mathrm{mg} \mathrm{KOH} / \mathrm{g}$ & 22,53 & 21,80 \\
Extrato etéreo $^{1}$ & $\%$ & 95,85 & 99,51 \\
Índice peróxido $^{1}$ & meq O$_{2} / \mathrm{kg}$ & 0,00 & 0,00 \\
Absorbância específica $^{2}$ & & \\
\multicolumn{2}{c}{$232 \mathrm{~nm}$} & 5,80 & 11,33 \\
$270 \mathrm{~nm}$ & 0,69 & 2,31
\end{tabular}

${ }^{1}$ Análises realizadas no Laboratório CBO Assessoria \& Análise, em Campinas, SP, em duplicata.

${ }^{2}$ Análises realizadas no Lab. Óleos e Gorduras da ESALQ/USP em Piracicaba/SP, em duplicata.

O óleo de vísceras foi oxidado através da exposição a altas temperaturas $\left(110\right.$ a $120^{\circ} \mathrm{C}$ ) durante o dia e à temperatura ambiente durante a noite. No processo de termoxidação, o calor fornece a energia necessária para ativação e formação dos radicais livres de ácidos graxos, que reagem com o oxigênio presente formando radicais livres de peróxidos. Esses radicais livres atacam ácidos graxos intactos e transformam-nos em novos radicais livres, propagando a oxidação dos lipídios insaturados. A ressonância e conseqüente conjugação das duplas ligações nas moléculas de ácidos graxos gera compostos dienos e trienos conjugados, dependendo do número de duplas ligações no ácido graxo. Finalmente, o processo chega ao seu término com a clivagem e o rearranjo dos compostos finais da oxidação produzindo polímeros ou compostos voláteis e alterações no odor, sabor e qualidade do óleo. O processo de oxidação térmica do óleo de vísceras utilizado neste estudo foi acompanhado pelo acúmulo de compostos dienos, peróxidos, trienos e voláteis presentes no óleo através da análise da absorbância específica na faixa espectral do ultravioleta (UV). A leitura das absorbâncias a 232 e 270 nm nas 
amostras do óleo oxidado ao final dos 20 dias sob altas temperaturas produziu valores duas vezes superior em $232 \mathrm{~nm}$ (dienos, peróxidos) e três vezes superior em $270 \mathrm{~nm}$ (trienos e voláteis), quando comparado com o óleo mantido congelado. Esse processo de termoxidação reduziu a umidade do produto e, conseqüentemente, concentrou os lipídios, aumentando o teor de extrato etéreo.

Tabela 3. Perfil de ácidos graxos do óleo de vísceras de aves fresco e oxidado usado na produção das rações experimentais $(n=1)$

\begin{tabular}{lcc}
\hline Ácidos Graxos (\%) & Óleo Fresco & Óleo Oxidado \\
\hline Ác. mirístico (C14:0) & 0,77 & 0,83 \\
Ác. palmítico (C16:0) & 27,70 & 29,70 \\
Ác. palmitoléico (C16:1) & 8,60 & 9,20 \\
Ác. esteárico (C18:0) & 6,60 & 6,30 \\
Ác. oléico (C18:1) & 38,20 & 38,90 \\
Ác. linoléico (C18:2) & 16,20 & 13,40 \\
Ác. linolênico (C18:3) & 0,03 & 0,09 \\
Total Saturados & 35,07 & 36,80 \\
Total Insaturados & 63,04 & 61,55 \\
\hline
\end{tabular}

Na Tabela 3 observa-se a composição de ácidos graxos do lote de óleo de vísceras utilizado neste estudo e a sua comparação com a composição do óleo após a oxidação. Esta comparação possibilita a visualização do efeito do processo de oxidação lipídica sobre o óleo, havendo uma sensível perda de ácido linoléico (C18:2), principal componente afetado no decorrer deste processo. Como os ácidos graxos são quantificados em porcentagem do total da área dos picos, a introdução do oxigênio na molécula insaturada pode provocar um comprometimento das duplas ligações, as moléculas mais insaturadas deixam de ser identificadas como tal, fazendo que haja um incremento artificial das espécies menos insaturadas, como revelado na Tabela 
3. Conseqüentemente, a proporção de ácidos graxos saturados e insaturados nas duas amostras de óleo também apresentou modificações, sendo a quantidade de insaturados bastante reduzida e a de saturados aumentada para o óleo oxidado.

Resultados semelhantes foram observados anteriormente por outros autores que submeteram óleos com quantidades consideráveis de ácidos graxos insaturados em sua composição ao processo de termoxidação. Engberg e colaboradores (1996) também encontraram "perda" de ácido linoléico (C18:2) e linolênico (C18:3) e conseqüente aumento na proporção do ácido esteárico (C18:0) em relação à porcentagem dos ácidos graxos, quando foram comparadas as composições em ácidos graxos do óleo vegetal fresco e do oxidado.

\subsubsection{Desempenho das aves}

Os valores médios de desempenho obtidos para os tratamentos estudados podem ser observados na Tabela 4. O fornecimento de óleo de vísceras de aves fresco ou oxidado não resultou em diferença estatística significativa para nenhuma das variáveis utilizadas para avaliar o desempenho das aves dos 10 aos 40 dias de idade $(P>0,05)$.

Tabela 4. Resultados médios de peso vivo aos 40 dias, consumo de ração, conversão alimentar e ganho de peso diário individual para os animais experimentais no período de 10 a 40 dias de idade

\begin{tabular}{lccc}
\hline Variáveis & Óleo Fresco & Óleo Oxidado & C.V. (\%) \\
\hline Peso Final $(\mathrm{kg})$ & 2,493 & 2,457 & 9,81 \\
Consumo de Ração $(\mathrm{kg})$ & 4,503 & 4,563 & 1,41 \\
Conversão Alimentar & 2,025 & 2,051 & 9,75 \\
Ganho Peso Diário $(\mathrm{kg})$ & 0,075 & 0,074 & 10,85 \\
\hline
\end{tabular}


Contudo, os resultados médios de conversão alimentar foram elevados para os dois tratamentos, mas devemos levar em conta que foi utilizada uma ração única dos 10 aos 40 dias de idade, o que pode ter afetado negativamente a conversão alimentar.

Além disso, o prejuízo na conversão alimentar verificado em ambos os tratamentos pode ter sido provocado pelas condições em que o óleo fresco e oxidado se encontravam, com índices altos de acidez. A presença de grandes quantidades de ácidos graxos livres neste produto pode ter sido responsável pelos prejuízos verificados na conversão alimentar dos animais experimentais de uma maneira geral, já que grandes proporções de ácidos graxos livres no intestino das aves prejudicam os processos de digestão e a absorção dos óleos ou gorduras, reduzindo a sua digestibilidade (Wiseman \& Salvador, 1991).

\subsubsection{Características da carcaça}

Os efeitos do fornecimento de óleo de vísceras fresco ou oxidado sobre o peso vivo e sobre as características da carcaça dos animais abatidos aos 41 dias de idade podem ser observados na Tabela 5 .

O uso de óleo oxidado na proporção de $4 \%$ na dieta das aves não prejudicou significativamente o peso vivo dos animais aos 41 dias de idade, nem tampouco o peso da carcaça eviscerada ou o rendimento da carcaça $(P>0,05)$. Nenhum efeito foi verificado para as variáveis: rendimento de perna, de carne de sobrecoxa ou quantidade de gordura abdominal depositada, seja em gramas ou em porcentagem $(P>0,05)$.

Contudo, os valores de rendimento do peito e da carne do peito $(P<0,07)$ foram significativamente reduzidos pelo uso do óleo oxidado na ração dos animais, quando comparados com o outro tratamento. 
Tabela 5. Valores médios obtidos de peso vivo ao abate (41 dias), peso da carcaça eviscerada (sem pés, cabeça e pescoço) e demais aspectos de rendimento das partes, além da gordura abdominal, para os tratamentos estudados $(n=68)$

\begin{tabular}{lccc}
\hline Parâmetros & Óleo Fresco & Óleo Oxidado & C.V. (\%) \\
\hline Peso Vivo (kg) & 2,363 & 2,346 & 6,30 \\
Peso Carcaça Eviscerada (kg) & 1,709 & 1,685 & 6,75 \\
Rendimento Carcaça (\%) & 72,34 & 71,84 & 2,50 \\
Rendimento Peito (\%) & $36,23^{\mathrm{a}}$ & $35,25^{\mathrm{b}}$ & 5,58 \\
Rendimento Carne Peito (\%) & $27,36^{\mathrm{a}}$ & $26,38^{\mathrm{b}}$ & 7,58 \\
Rendimento Perna (\%) & 31,79 & 32,04 & 3,98 \\
Rendimento Carne Sobrecoxa (\%) & 12,74 & 13,20 & 10,63 \\
Gordura abdominal (g) & 39,65 & 42,54 & 40,15 \\
Gordura abdominal (\%) & 2,32 & 2,52 & 38,93 \\
${ }^{\text {ab }}$ Médias na mesma linha diferem estatisticamente entre si (P<0,01) pelo teste t. &
\end{tabular}

Os estudos que avaliam as características da carcaça, como o rendimento, e o fornecimento de fontes de energia geralmente relacionam os níveis de energia fornecidos através da dieta. No caso deste estudo, a fonte de energia utilizada, o óleo de vísceras de aves fresco ou oxidado, pode ter levado a uma variação nos níveis energéticos das rações experimentais. Com base nos resultados de energia metabolizável apresentados no Capítulo 3, a perda de energia na ração contendo óleo oxidado pode ser estimada em cerca de 60 $\mathrm{kcal} / \mathrm{kg}$ de ração. Este déficit energético da ração contendo óleo oxidado pode ter comprometido a deposição de proteína muscular e resultado em menores índices de rendimento do músculo do peito. 


\subsubsection{Características da carne de sobrecoxa}

A composição centesimal da carne de sobrecoxa dos animais experimentais, bem como os valores médios de $\mathrm{pH}$ medido 24 horas após o abate estão apresentados na Tabela 6. Não houve diferença entre os tratamentos em nenhuma dessas variáveis $(P>0,05)$.

Os resultados médios obtidos neste estudo para a umidade, proteína bruta e matéria mineral estão abaixo dos valores encontrados na literatura (USDA National Nutrient Database for Standard Reference, Release 16-1, 2004). Conseqüentemente, a quantidade de lipídios encontrada foi superior considerando-se a essa mesma tabela e outros autores brasileiros (Franco, 2001 e Mendes, 2001).

Tabela 6. Valores médios de umidade, proteína bruta, gordura, matéria mineral e $\mathrm{pH}$ da carne de sobrecoxa $(n=3)$

\begin{tabular}{lcccc}
\hline Análises $^{1}$ & Unidades & Óleo Fresco & Óleo Oxidado & CV (\%) \\
\hline Umidade & $\%$ & 71,33 & 69,03 & 7,78 \\
Proteína Bruta & $\%$ & 15,49 & 16,50 & 9,09 \\
Gordura & $\%$ & 12,47 & 12,73 & 3,26 \\
Matéria mineral & $\%$ & 0,25 & 0,23 & 11,83 \\
$\mathrm{pH}^{2}$ & & 5,93 & 6,02 & 1,09 \\
\hline
\end{tabular}

${ }^{1}$ Análises efetuadas em duplicata.

${ }^{2}$ Análise realizada $24 \mathrm{~h}$ após o abate, em duplicata.

A composição química dos músculos das aves depende de diversos fatores como genética, nutrição, idade e ambiente, de acordo com Mendes (2001); sendo assim, é possível ocorrer uma variação entre a composição encontrada e a apresentada nas tabelas, dadas as possíveis diferenças entre os músculos analisados.

Os valores de $\mathrm{pH}$ encontrados para a carne de sobrecoxa 24 horas após o abate estão um pouco abaixo dos níveis normalmente 
encontrados, que estão em torno de 6,20 e 6,70, segundo Mendes (2001). Contudo, os valores de $\mathrm{pH}$ encontrados no decorrer dos nove meses de armazenamento a $-18{ }^{\circ} \mathrm{C}$ estavam em concordância com estes padrões (valores médios de 6,24 e 6,20 para a carne dos animais que consumiram rações contendo óleo fresco e oxidado, respectivamente).

A composição dos ácidos graxos da fração lipídica da carne de sobrecoxa dos animais submetidos aos tratamentos estudados está apresentada na Tabela 7. O perfil encontrado está de acordo com o normalmente verificado para esse músculo, com algumas pequenas variações, mas a maior proporção dos ácidos graxos está representada pelos de cadeias de 16 e 18 carbonos, conforme observado anteriormente por Asghar et al. (1989) e Lin et al. (1989a).

Tabela 7. Perfil dos ácidos graxos (\%) da fração lipídica das amostras de carne de sobrecoxa $(n=3)$

\begin{tabular}{lccc}
\hline \multirow{2}{*}{ Ácidos Graxos } & \multicolumn{3}{c}{ Tratamentos } \\
& Óleo Fresco & Óleo Oxidado & CV (\%) \\
\hline C14:0 mirístico & 0,69 & 0,65 & 7,0 \\
C16:0 palmítico & 24,37 & 26,40 & 4,3 \\
C16:1 palmitoléico & 6,83 & 8,17 & 14,3 \\
C18:0 esteárico & 6,27 & 5,57 & 10,9 \\
C18:1 oléico & 39,47 & 40,57 & 4,6 \\
C18:2 linoléico & 20,80 & 18,67 & 6,8 \\
\hline
\end{tabular}

Foram encontradas pequenas variações nas proporções dos ácidos graxos das amostras de carne dos dois tratamentos estudados. Os ácidos palmítico (C16:0), palmitoléico (C16:1) e oléico (C18:1) apresentaram um ligeiro aumento e houve uma pequena redução nas concentrações dos ácidos mirístico (C14:0) e esteárico (C18:0). Porém, a maior diferença foi verificada na quantidade de ácido linoléico (C18:2), que apresentou uma 
redução quando o óleo fresco foi substituído pelo óleo oxidado na dieta das aves, resultado do comprometimento das duplas ligações com a entrada do oxigênio na molécula (Tabela 3 ).

\subsubsection{Ensaio de armazenamento congelado}

\subsubsection{Valores de TBARS}

Os valores de TBARS analisados periodicamente nas amostras de sobrecoxa e apresentados na Tabela 8 e na Figura 1 fornecem um indicativo da influência da qualidade do óleo utilizado na dieta das aves sobre o estado oxidativo das sobrecoxas armazenadas sob congelamento. Os resultados médios variaram de 0,164 a $0,497 \mathrm{mg}$ de malonaldeídos $/ \mathrm{kg}$ de amostra para o tratamento com uso de óleo fresco na ração e de 0,160 a 0,775 mg de malonaldeídos $/ \mathrm{kg}$ de amostra para o tratamento com uso de óleo oxidado na ração das aves.

A formação de compostos de ranço nas amostras de carne de sobrecoxa crua armazenada sob congelamento ocorreu de forma crescente no decorrer do tempo, conforme esperado. Os valores de TBARS encontrados nas amostras de carne provenientes dos animais que consumiram óleo oxidado na dieta aumentaram significativamente a partir do sexto mês, quando comparados com os valores encontrados para o outro tratamento. Estes resultados estão em concordância com os apresentados anteriormente por Jensen et al. (1997), que armazenou carne crua de peito e de sobrecoxa provenientes de frangos alimentados com óleo vegetal fresco ou oxidado e armazenados sob congelamento. A inclusão de óleo oxidado na dieta dos frangos levou a uma menor retenção de $\alpha$-tocoferol nos tecidos animais e, conseqüentemente, a uma menor estabilidade oxidativa destes tecidos, expressa nos valores de TBARS significativamente superiores $(P<0,01)$ depois de nove meses de armazenamento congelado. 
Tabela 8. Valores médios de TBARS, seus respectivos desvios e significância estatística para as amostras de carne de sobrecoxa armazenadas durante nove meses sob congelamento $(n=3)$

\begin{tabular}{cccc}
\hline Meses & \multicolumn{2}{c}{ TBARS $(\mathrm{mg}$ malonaldeído/kg amostra) } & \\
& Óleo Fresco & Óleo Oxidado & $\mathrm{P}^{1}$ \\
\hline 0 & $0,164 \pm 0,057$ & $0,160 \pm 0,013$ & $\mathrm{~ns}^{2}$ \\
1 & $0,291 \pm 0,026$ & $0,243 \pm 0,040$ & $\mathrm{~ns}$ \\
2 & $0,257 \pm 0,095$ & $0,236 \pm 0,029$ & $\mathrm{~ns}$ \\
3 & $0,156 \pm 0,072$ & $0,155 \pm 0,023$ & $\mathrm{~ns}$ \\
4 & $0,348 \pm 0,072$ & $0,367 \pm 0,065$ & $\mathrm{~ns}$ \\
5 & $0,462 \pm 0,067$ & $0,474 \pm 0,037$ & $\mathrm{~ns}$ \\
6 & $0,453 \pm 0,101$ & $0,613 \pm 0,074$ & 0,10 \\
7 & $0,469 \pm 0,039$ & $0,775 \pm 0,117$ & 0,05 \\
9 & $0,497 \pm 0,019$ & $0,758 \pm 0,330$ & $\mathrm{~ns}$ \\
\hline
\end{tabular}

${ }^{1}$ Valores de probabilidade determinados pelo teste $t$

${ }^{2}$ ns=não significativo

Da mesma forma, os resultados encontrados neste estudo, demonstram que a presença do óleo de vísceras de aves oxidado na dieta das aves prejudica a estabilidade da carne de sobrecoxa, comprovando que a qualidade do óleo fornecido na dieta pode comprometer o armazenamento posterior, mesmo sob congelamento. 


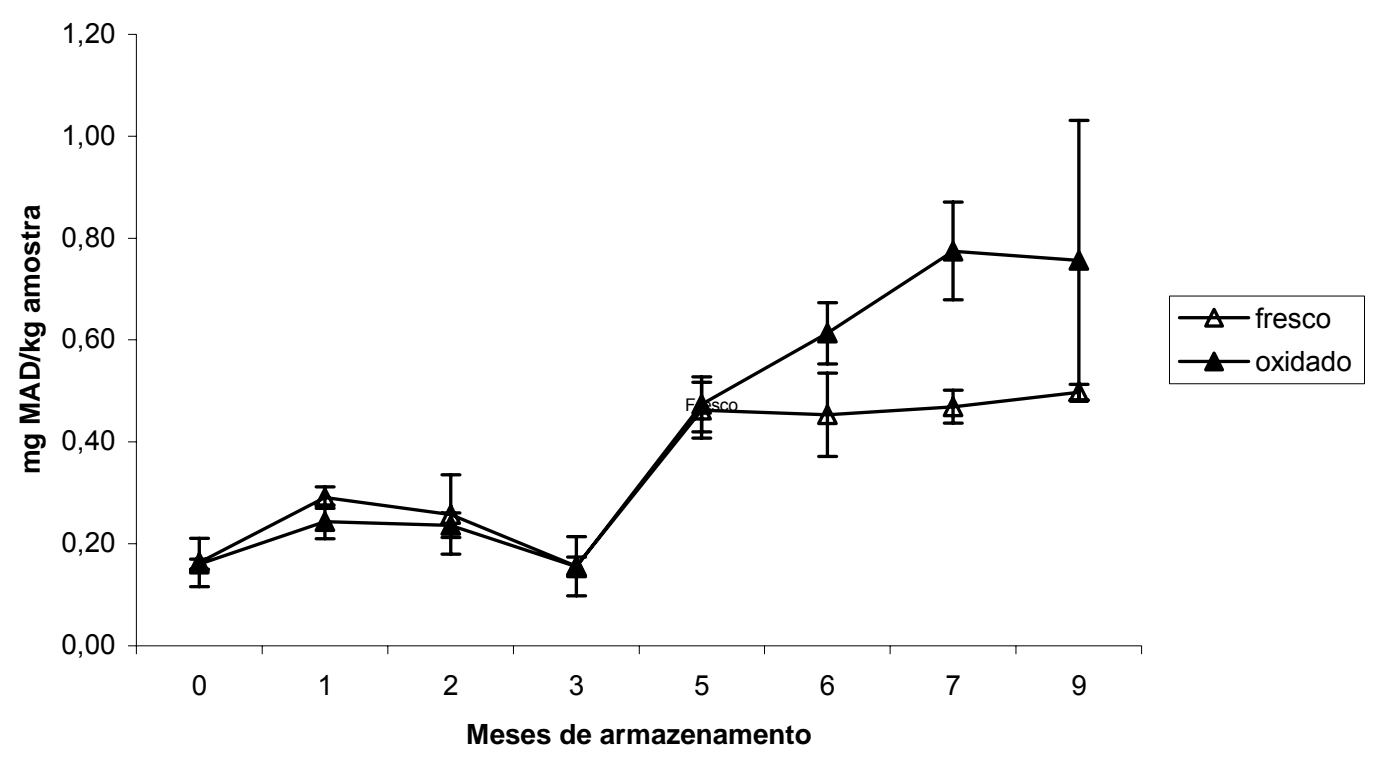

Figura 1 - Progressão da oxidação lipídica na carne congelada de sobrecoxa das aves alimentadas com rações contendo óleo fresco ou oxidado

Apesar dos valores máximos de TBARS neste estudo não terem ultrapassado 0,800 $\mathrm{mg}$ malonaldeído/kg amostra, alguns autores afirmam que, em equipes de provadores treinados, indivíduos podem ser capazes de detectar odores desagradáveis em carnes oxidadas com valores de TBARS a partir de 0,500 a 2,00 mg malonaldeído/kg carne (Galvin et al., 1997); no entanto, o mesmo não pode ser extrapolado para o público consumidor em geral. De qualquer forma, este trabalho evidencia que gorduras em estado mais adiantado de oxidação, quando adicionadas às rações, podem afetar a qualidade da carne e sua estabilidade oxidativa.

\subsubsection{Cor}

A oxidação dos lipídios é considerada a principal causa de perda de qualidade em carnes e produtos cárneos, pois pode afetar aspectos como textura, odor, valor nutritivo e segurança alimentar, além da cor do produto (Morrisey et al., 2003). Para Jensen et al. (1998), a intensidade de descoloração 
de carnes frescas está diretamente relacionada com a oxidação dos pigmentos e com a eficiência dos sistemas enzimáticos, mas o completo funcionamento dos mecanismos de manutenção da cor das carnes ainda não está estabelecido. Sendo a cor um importante atributo que influencia a aceitação dos alimentos pelo consumidor (Quiao et al., 2001), inclusive a carne de frango, uma atenção especial deve ser dada a este parâmetro de qualidade.

Para a comparação dos valores de $L^{*}, a^{*}$ e $b^{*}$ das carnes armazenadas foram calculadas as médias de quatro leituras por amostra, em três amostras por tratamento, durante todos os nove meses de ensaio. Os valores mensais obtidos para $L^{*}, a^{*}$ e $b^{*}$ estiveram dentro dos padrões normais para a carne de sobrecoxa e não apresentaram diferenças significativas entre os tratamentos. Para as determinações de luminosidade $\left(L^{*}\right)$ obteve-se média de 46,57 , para o tratamento fresco e de 47,09 , para o oxidado. Para as leituras de $a^{*}$ e $b^{*}$ as médias foram de 11,30 e 9,12, para o tratamento fresco e de 10,60 e 10,01, para o tratamento oxidado, respectivamente. Assim sendo, o fornecimento de óleo de vísceras oxidado não provocou modificações na coloração da carne de sobrecoxa congelada ao longo dos nove meses de armazenamento.

\subsection{Conclusões}

O consumo de ração contendo óleo de vísceras oxidado não resultou em prejuízo ao desempenho ou ao rendimento de carcaça de frangos de corte, mas houve redução no rendimento de peito.

Houve perda de estabilidade oxidativa das sobrecoxas dos frangos alimentados com rações contendo óleo de vísceras de aves oxidado e isso se manifestou após seis meses de armazenamento sob congelamento. 


\section{CONCLUSÕES GERAIS}

O processo de oxidação lipídica levou a um decréscimo no valor biológico do óleo de vísceras de aves. No entanto, ao ser incorporado às rações e fornecido a frangos de corte na proporção de $4 \%$, este óleo não causou prejuízos ao desempenho das aves nem às características da carcaça. O consumo de rações contendo $4 \%$ de óleo de vísceras de aves oxidado prejudicou a estabilidade oxidativa da carne de sobrecoxa armazenada sob refrigeração e sob congelamento. 


\section{REFERÊNCIAS BIBLIOGRÁFICAS}

ADAMS, C.A. Nutricines: food components in health and nutrition. Nottingham: Nottingham University Press, 1999. cap. 2, p.11-32: Oxidation and antioxidants.

ALBINO, L.F.T.; NASCIMENTO, A.H.; VALÉRIO, S.R. Níveis de energia da dieta e da temperatura ambiente sobre a composição da carcaça em frangos (músculo e gordura). In: SIMPÓSIO INTERNACIONAL SOBRE DESENVOLVIMENTO DE CARCAÇA DE FRANGOS: OSSO, MÚSCULO, GORDURA E PENA; CONFERÊNCIA APINCO, Campinas, 2000. Anais. Campinas: FACTA. p.63-79.

ALLEN, C.D.; FLETCHER, D.L.; NORTHCUTT, J.K.; RUSSEL, S.M. The relationship of broiler breast color to meat quality and shelf-life. Poultry Science, v.77, p.361-366, 1998.

AMERICAN OIL CHEMIST'S SOCIETY. Official and tentative methods. Champaign, 1990. 1v.

ASGHAR, A.; LIN, C.F.; GRAY, J.I.; BUCKLEY, D.J., BOOREN, A.M.; CRACKEL, R.L.; FLEGAL, C.J. Influence of oxidised dietary oil and antioxidant supplementation on membrane-bound lipids stability in broiler meat. British Poultry Science, v.30, p.815-823, 1989. 
ANDERSEN, M.L.; LAURIDSEN, R.K.; SKIBSTED, L.H. Optimising the use of phenolic compounds. Cambridge: CRC Press, 2003. p. 315-346: Phytochemical functional foods.

ASSOCIATION OF OFFICIAL ANALYTICAL CHEMISTS. Official methods of analysis. 15. ed. Washington, 1995. 2v.

BALNAVE, D. Essential fatty acids in poultry nutrition. World's Poultry Science Journal, v.26, p.442-460, 1970.

BLIGH, E.G.; DYER, W. J. A rapid method of total lipid extraction and purification. Canadian Journal of Biochemistry and Physiology, v. 37, n.8, p. 911-917, Aug.1959.

BOU, R.; GUARDIOLA, F.; GRAU, A.; GRIMPA, S.; MANICH, A.; BARROETA, A.; CODONY, R. Influence of dietary fat source, $\propto$-tocopherol, and ascorbic acid supplementation on sensory quality of dark chicken meat. Poultry Science, v.80, p.800-807, 2001.

BOULIANNE, M.; KING, A.J. Biochemical and color characteristics of skinless boneless pale chicken breast. Poultry Science, v.74, p.1693-1698, 1995.

BRASIL. Ministério da Agricultura. Compêndio brasileiro de nutrição animal. Brasília, 1998. 1 v.

BUCKLEY, D.J.; MORRISEY, P.A.; GRAY, J.I. Influence of dietary vitamin E on oxidative stability and quality of pig meat. Journal of Animal Science, v.73, p.3122-3130, 1995. 
CABEL, M.C.; WALDROUP, P.W.; SHERMER, W.; CALABOTTA, D.F. Effects of ethoxyquim feed preservative and peroxide level on broiler performance. Poultry Science, v.67, p.1725-1730, 1988.

CHEN, B.H.; CHEN, Y.C. Evaluation of the analysis of cholesterol oxides by liquid chromatography. Journal of Chromatography, v.661, p.127-136, 1994.

CHRISTIE, W.W. Chromatographic and spectroscopic analysis of lipids. General principles. In: CHRISTIE, W.W. Lipid analysis. Oxford: Pergamon Press, 1982. cap.3, p.25-49.

COMBS, G.F. The vitamins. London: Academic Press, 1998. cap.7, p. 189222: Vitamin E.

DIBNER, J.J.; ATWELL, C.A.; KITCHELL, M.L.; SHERMER, W.D.; IVEY, F.J. Feeding of oxidised fats to broilers and swine: effects on enterocyte turnover, hepatocyte proliferation and gut associated lymphoid tissue. Animal Feed Science and Technology, v.62, p.1-13, 1996.

ENGBERG, R.M.; LAURIDSEN, C.; JENSEN, S.K.; JAKOBSEN, K. Inclusion of oxidised vegetable oil in broiler diets. Its influence on nutrient balance and on antioxidative status of broilers. Poultry Science, v.75, p.1003-1011,1996.

ESTADOS UNIDOS. Department of Agriculture. Agricultural Research Service. 2004. USDA National Nutrient Database for Standard Reference, Release 16-1. Nutrient Data Laboratory Home Page. http://www.nal.usda.gov/fnic/foodcomp/ (29/05/2004). 
FRANCO, G. Tabela de composição química dos alimentos. 9.ed. São Paulo: Editora Atheneu, 2001. 356p.

FRIEDMAN, A.; SKLAN, D. Effect of dietary fatty acids on humoral immune response of turkeys. British Poultry Science, v.38, p.342-348, 1997.

GALVIN, K.; MORRISSEY, P.A.; BUCKLEY, D. J. Influence of dietary vitamin E and oxidised sunflower oil on the storage stability of cooked chicken muscle. British Poultry Science, v.38, p.499-501, 1997.

GRAY, J.I.; GOMAA, E.A.; BUCKLEY, D.J. Oxidative quality and shelf life of meats. Meat Science, v.43, S111-S123, 1996.

GRAU, A.; CODONY, R.; GRIMPA, S.; BAUCELLS, M.D.; GUARDIOLA, F. Cholesterol oxidation in frozen dark meat: Influence of dietary fat source, and $\propto$-tocopherol and ascorbic acid supplementation. Meat Science, v. 57 , p.197-208, 2001a.

GRAU, A.; GUARDIOLA, F.; GRIMPA, S.; BARROETA, A. C.; CODONY, R. Oxidative stability of dark chicken meat through frozen storage: influence of dietary fat and $\propto$-tocopherol and ascorbic acid supplementation. Poultry Science, v.80, p.1630-1642, 2001b.

HARTMAN, L.; LAGO, R. C. Rapid determination of fatty acid methyl esthers from lipids. Laboratory Practice, v.22, n.7, p.475-476, 1973. 
INTERNATIONAL UNION OF PURE AND APPLIED CHEMISTRY. Standard methods for analysis of oils, fat and derivates. 6.ed. Thiais: Pergamon Press, 1979. 2v.

JENSEN, C.; LAURIDSEN, C.; BERTELSEN, G. Dietary vitamin E: quality and storage stability of pork and poultry. Trends in Food Science and Technology, v.9, p.62-72, 1998.

JENSEN, C.; ENGBERG, R.; JAKOBSEN, K.; SKIBSTED, L.H.; BERTELSEN, G. Influence of the oxidative quality of dietary oil on broiler meat storage stability. Meat Science, v.47, p.211-222, 1997.

LAURIDSEN, C.; BUCKLEY, D.J.; MORRISEY, P.A. Influence of dietary fat and vitamin $\mathrm{E}$ supplementation on $\alpha$-tocopherol levels and fatty acid profiles in chicken muscle membranal fraction and susceptibility to lipid oxidation. Meat Science, v.46, p.9-22, 1997.

LIN, C.F.; GRAY, J.I.; ASGHAR, A.; BUCKLEY, D.J.; BOOREN, A.M.; FLEGAL, C.J. Effects of dietary oils and $\alpha$-tocopherol supplementation on lipid composition and stability of broiler meat. Journal of Food Science, v.54, p.1457-1484, 1989a.

LIN, C.F.; ASGHAR, A.; GRAY, J.I.; BUCKLEY, D.J.; BOOREN, A.M.; CRACKEL, R.L.; FLEGAL, C.J. Effects of oxidized dietary oil and antioxidant supplementation on broiler growth and meat stability. British Poultry Science, v.30, p. 855-864, 1989b. 
MARMER, W.N., MAXWELL, R.J. Dry column method for the quantitative extraction and simultaneous class separation of lipids from muscle tissue. Lipids, v.16, p.365-367, 1981.

MATTERSON, L.D.; POTTER, L.M.; STUTZ, N. et al. The metabolizable energy of feed ingredients for chickens. Research Report, v.7, p. 3-11, 1965.

MENDES, A. A. Rendimento e qualidade da carcaça de frangos de corte. In: CURSO BÁSICO DE MANEJO DE FRANGOS DE CORTE CONFERÊNCIA APINCO; Campinas, 2001. Anais. Campinas: FACTA, 2001. p.79-99.

MORRISSEY, P.A.; KERRY, J.P.; GALVIN, K. Lipid oxidation in muscle foods.

In: ACS Symposium Series: Freshness and shelf life of foods. Washington: American Chemical Society, 2003. p. 188-200. (ACS. Simposium Series, 836).

MORRISEY, P.A.; BRANDON, S.; BUCKLEY, D.J.; SHEEHY, P.J.A.; FRIGG, M. Tissue content of $\alpha$-tocopherol and oxidative stability of broilers receiving dietary $\alpha$-tocopheryl acetate supplement for various periods pré slaughter. British Poultry Science, v.38, p. 84-88, 1997.

MORRISSEY, P.A.; SHEEHY, P.J.; GALVIN, K.; KERRY, J.P.; BUCKLEY, D. J. Lipid stability in meat and meat products. Meat Science, v.49, n.1, S73S86, 1998.

NATIONAL RESEARCH COUNCIL. Nutrient requirements of poultry. 9. ed. Washington: National Academy Press, 1994. 71 p. 
OLIVO, R.; SHIMOKOMAKI, M. Carnes: no caminho da pesquisa. 2.ed. Cacoal do Sul: Imprint, 2002. 155p.

O'NEILL, L.M.; GALVIN, K.; MORRISEY, P.A.; BUCKLEY, D.J. Inhibition of lipid oxidation in chicken by carnosine and dietary $\alpha$-tocopherol supplementation and its determination by derivative spectrophotometry. Meat Science, v.50, p.479-488, 1998.

O'NEILL, L.M.; GALVIN, K.; MORRISEY, P.A.; BUCKLEY, D.J. Effect of carnosine, salt and vitamin $\mathrm{E}$ on oxidative stability of chicken meat. Meat Science, v.52, p.89-94, 1999.

QIAO, M.; FLETCHER, D.L.; SMITH, D.P.; NORTHCUTT, J.K. The effect of broiler breast meat color on $\mathrm{pH}$, moisture, water-holding capacity, and emulsification capacity. Poultry Science, v.80, p.676-680, 2001.

RHEE, K.S.; ANDERSON, L.M.; SAMS, A.R. Lipid oxidation potential of beef, chicken and pork. Journal of Food Science, v.61, p.8-12, 1996.

ROBEY, W. Preventing the negative effects of nutrient oxidation on animal nutrition and performance. Nutrition Update, v.4, n.2, p. 1-10, 1994.

ROBEY, W.; SHERMER, W. The damaging effects of oxidation. Feed Mix, v.2, n.5, p.22-26, 1994.

ROSTAGNO, H.S. Tabelas brasileiras para aves e suínos: composição de alimentos e exigências nutricionais. Viçosa: UFV, Departamento de Zootecnia, 2000. 141 p. 
SAS INSTITUTE. SAS: user's guide. version 6.11. 4.ed. Cary, 1996. 956 p.

SCOTT, M.L.; NESHEIN, M.C.; YOUNG, R.J. Nutrition of the chicken. 3. ed. Ithaca : M. L. SCOTT \& Associates, 1982. 562 p.

SHEEHY, P.J.A.; MORRISSEY, P.A.; FLYNN, A. Consumption of thermally oxidized sunflower oil by chicks reduces $\alpha$-tocopherol status and increases susceptibility of tissues to lipid oxidation. British Journal of Nutrition, v.71, p.53-65, 1994.

SHELDON, B.W.; CURTIS, P.A.; DAWSON, P.L.; FERKET, P.R. Effect of dietary vitamin $\mathrm{E}$ on oxidative stability, flavour, color, and volatile profiles of refrigerated and frozen turkey breast meat. Poultry Science, v.76, p.634641, 1997.

SMEDES, F; THOMASEN, T.K. Evaluation of the bligh and dyer lipid determination method. Marine Pollution Bulletin, v.32, n.8/9, p. 681-688, 1996.

TARLADGIS, B.G.; WATTS, B.M.; YOUNATHAN, M.T. A distillation method for the quantitative determination of malonaldehyde in rancid foods. Journal of the American Oil Chemist's Society, v.37, n.1, p.44-48, 1960.

VAN LAACK, R.L.J.M.; LIU, C.H.; SMITH, M.O.; LOVEDAY, H.D. Characteristics of pale, soft, exudative broiler breast meat. Poultry Science, v.79, p.1057-1061, 2000. 
WALDROUP, P.W.; DOUGLAS, C.R.; McCALL, J.T.; HARMS, R.H. The effects of Santoquim ${ }^{\circledR}$ on the performance of broilers. Poultry Science, v.39, p.1313-1317, 1960.

WHITE, P. Conjugated diene, anisidine value, and carbonyl value analyses. In: WARNER, K.; ESKIN, M. Methods to assess quality and stability of oils and fat-containing foods. Champaign: AOCS Press, 1995. p.159-178.

WISEMAN, J.; SALVADOR, F. The influence of free fatty acid content and degree of saturation on the apparent metabolizable energy value of fats fed to broilers. Poultry Science, v. 70, p. $573-582,1991$. 